Article

\title{
Spatial Assessment of the Bioclimatic and Environmental Factors Driving Mangrove Tree Species' Distribution along the Brazilian Coastline
}

\author{
Arimatéa C. Ximenes ${ }^{1,2, *}$, Eduardo Eiji Maeda ${ }^{3}$, Gustavo Felipe Balué Arcoverde ${ }^{4}$ \\ and Farid Dahdouh-Guebas ${ }^{1,2}$ \\ 1 Laboratory of Systems Ecology and Resource Management, Université Libre de Bruxelles-ULB, \\ Brussels 1050, Belgium; fdahdouh@ulb.ac.be \\ 2 Laboratory of Plant Biology and Nature Management, Vrije Universiteit Brussel-VUB, \\ Brussels 1050, Belgium \\ 3 Department of Geosciences and Geography, University of Helsinki, P.O. Box 68, Helsinki FI-00014, Finland; \\ eduardo.maeda@helsinki.fi \\ 4 Science Center of Earth System, National Institute for Space Research-INPE, São José dos Campos 1227-010, \\ Brazil; gustavo.arcoverde@inpe.br \\ * Correspondence: ximenes@protonmail.com; Tel.: +32-2-650-2137
}

Academic Editors: Deepak R. Mishra, Richard W. Gould Jr. and Prasad S. Thenkabail Received: 18 March 2016; Accepted: 18 May 2016; Published: 27 May 2016

\begin{abstract}
Brazil has one of the largest mangrove surfaces worldwide. Due to a wide latitudinal distribution, Brazilian mangroves can be found within a large range of environmental conditions. However, little attention has been given to the description of environmental variables driving the distribution of mangrove species in Brazil. In this study, we present a novel and unprecedented description of environmental conditions for all mangroves along the Brazilian coast focusing on species limits. We apply a descriptive statistics and data-driven approach using Self-Organizing Maps and we combine data from terrestrial and marine environmental geodatabases in a Geographical Information System. We evaluate 25 environmental variables ( 21 bioclimatic variables, three sea surface temperature derivates, and salinity). The results reveal three groups of correlated variables: (i) air temperature derivates and sea surface temperature derivates; (ii) air temperature, potential evapotranspiration and precipitation derivates; and (iii) precipitation derivates, aridity and salinity. Our results unveil new locations of extreme values of temperature and precipitation. We conclude that Rhizophora harrisonii and Rhizophora racemosa are more limited by precipitation and aridity and that they do not necessarily follow a latitudinal gradient. Our data also reveal that the lowest air temperatures of the coldest month are not necessarily found at the southernmost limits of mangroves in Brazil; instead they are localized at the Mesoregion of Vale do Itajaí. However, the minimum sea surface temperature drops gradually with higher latitudes in the Brazilian southern hemisphere and is probably a better indicator for the decrease of species at the latitudinal limits of mangroves than the air temperature and precipitation.
\end{abstract}

Keywords: wetland; climate; conservation; remote sensing; data-driven; data intensive science; Rhizophoraceae; Acanthaceae

\section{Introduction}

Understanding the influence of climate on the distribution of mangrove species is still a major challenge for science. Previous studies have shown that rainfall and temperature are commonly the main drivers of forest structure and species composition variability in the tropics [1]. However, in regions such as the Brazilian coast, where the latitudinal gradient is associated with a large 
climatic variability, the environmental conditions driving mangrove characteristics are still not fully understood [2,3].

Strikingly, only one study carried out by Schaeffer-Novelli et al. [2] has so far assessed the environmental factors on the coastline range of the Brazilian mangroves that was instrumental in improving our understanding of mangrove ecosystems. At the time of the study [2], several bottlenecks limited a more comprehensive and detailed assessment to understand the main climate pattern for Brazilian mangroves. However, the climatic database used by the previous study [2] is over 40 years old (Brazilian Ministry of Agriculture, 1972) with few climatic data samples coming mainly from states' capitals. Given these bottlenecks, the spatial variability of environmental conditions in the major Brazilian coastal mangroves is still unknown, considerably increasing uncertainties on the characterization of mangrove structure and species' composition.

Currently, the availability of satellite data for ocean, meteorological stations and spatially interpolated climate surfaces with high resolution have improved environmental information in sites where there is a lack of local data [4-6] and have integrated them in Geographical Information Systems (GIS). These remote sensing products and spatially interpolated surfaces enable us to obtain information that a few decades ago was not available. Thus far, the most recent environmental databases [4-6] and mangrove mappings [7-9], have not yet been used to update the environmental characterization of Brazilian mangroves. Therefore this large quantity of data creates an opportunity for scientists that requires new big data analysis techniques and tools [10-12]. Responding to this need, science that takes a "data-driven" approach is now emerging [10] in which the information is extrapolated from the data.

In this context, the Self-Organizing Maps (SOM) [13] provide a "data-driven" approach that it is supported by tools of data representation, mainly characteristic of data abstraction enhanced by visualization techniques [14,15]. The SOM have been used in several applications, such as mapping ecological and biogeographical features [16-20], determination of the most suitable sites for forest restoration [21] and selecting bioclimatic variables for species distribution modeling in the Brazilian north region [22]. The main advantage of the SOM algorithm as a data-driven approach is that it does not need to assume any a priori hypotheses [14,23]; it still has a robustness when data behavior is unknown and it shows the multivariate data cloud through visualization tools $[14,23]$ or rather as geovisualization tools [14]. The SOM's ability to preserve the topological structure of the input data $[14,23]$ provides a powerful advantage in studies with geospatial analysis [15]. Giraudel and Lek [24] compared the SOM with Principal Component Analysis (PCA) and Correspondence Analysis and they found similar results, with the latter two validating the SOM methods. Hence, SOM or a combination of SOM and ordination analysis seems to be a promising technique in ecological studies to explore multivariate data.

This study focuses on the ecological biogeography of finding patterns in the distribution of species that are constrained by bioclimatic and environmental variables [25], and due to the wide latitudinal and longitudinal range of the Brazilian mangroves, climate has a strong influence on the delimitation of species limits.

In short, we address the following questions: Which environmental variables influence the spatial distribution of mangrove species? Can the bioclimate and environmental data at higher temporal and spatial resolution improve the characterization of the Brazilian mangrove ecosystems? To answer these questions, we have set out four objectives: (i) to update the information on climatic and salinity conditions in Brazilian mangroves using the most recent environmental databases; (ii) to overcome data gaps found in the previous studies; (iii) to cluster relevant environmental variables according to their spatial dependence; and (iv) to provide a better understanding of the fundamental niche [26] of the mangrove plant species. With that in mind, we present an unprecedented data-intensive approach for the assessment of the environmental variables that drive species composition/distribution in mangroves along the entire Brazilian coastline. 


\section{Material and Methods}

\subsection{Study Area}

Brazil has one of the largest areas and extension of mangroves found from the northern coast, starting at the Oiapoque River $\left(04^{\circ} 30^{\prime} \mathrm{N}\right)$ in the state of Amapá, to the southern coast in the state of Santa Catarina $\left(28^{\circ} 30^{\prime} S\right)$ [2,7]. There is a minor discrepancy in its estimated size: it ranks third with a total of $7 \%$ of the global mangrove forests [9] while Spalding et al. [8] rank it second with a total of $8.5 \%$ of mangrove area worldwide. All in all, Brazil contains a huge area with approximately $50 \%$ of South America's mangroves [27] stretching over a $6780 \mathrm{~km}$ coastline [28].

Brazil is politically divided in 26 states, among which 16 are lined with mangroves (Figure 1) and were represented in the neural map. We represent these 16 political divisions to be in the neural map, because they are commonly used to define public policy in Brazil. Furthermore, these political boundaries provide more coastal segments than the seven regions proposed by Schaeffer Novelli et al. [2]. However, because the political boundaries or states are not ecologically representative, we also used the latitudinal variation as an independent variable for the scatterplots.

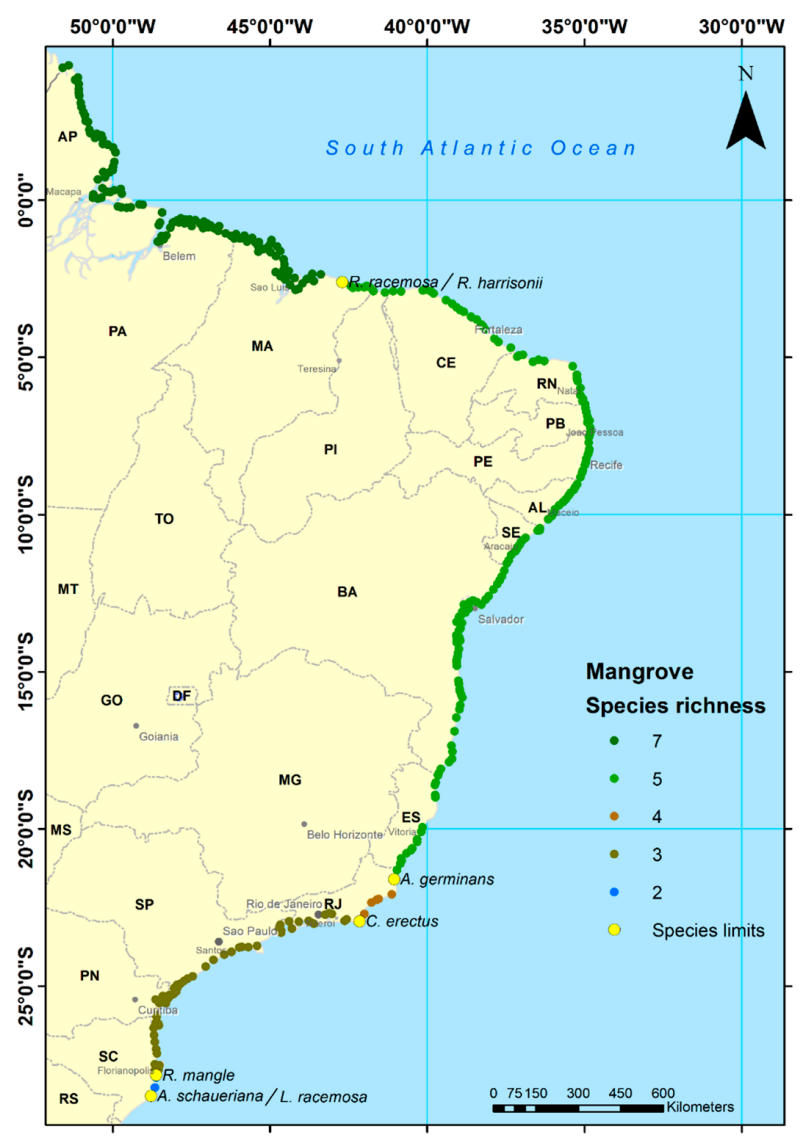

Figure 1. Mangrove species richness. The sample point distribution of Brazilian mangroves is colored by species richness $(n=390)$ and the species limits are shown by yellow circles (detailed information in Table 1). Brazil has 16 coastal states with mangroves. Two-letter codes represent States, whereas dots represent our samples, both of which are given below between parentheses. In the north, we have: Amapá (AP-34) and Pará (PA—64); in the northeast: Maranhão (MA-70), Piauí (PI-3), Ceará (CE-19), Rio Grande do Norte (RN-15), Paraíba (PB-10), Pernambuco (PE-10), Alagoas (AL-13), Sergipe (SE-11) and Bahia (BA-57); in the southeast: Espírito Santo (ES-15), Rio de Janeiro (RJ-25), São Paulo (SP-16); and in the south: Paraná (PR-11) and Santa Catarina (SC-17). 
Table 1. Brazilian mangroves species and their respective distribution limits from north to south (summary adapted from [29]).

\begin{tabular}{|c|c|c|c|c|c|c|}
\hline \multirow{2}{*}{ Species } & \multirow{2}{*}{$\begin{array}{c}\text { Species } \\
\text { Abbreviation }\end{array}$} & \multirow{2}{*}{ Family } & \multirow{2}{*}{ Location } & \multicolumn{2}{|c|}{ Latitude } & \multirow{2}{*}{ STATE } \\
\hline & & & & Degrees & Decimal & \\
\hline Rhizophora harrisonii Leechman & R. harrisonii & Rhizophoraceae & Preguiças River & $2^{\circ} 40^{\prime} \mathrm{S}$ & $2.6^{\circ} \mathrm{S}$ & Maranhão, MA \\
\hline Rhizophora racemosa G.F.W. Meyer & R. racemosa & Rhizophoraceae & Preguiças River & $2^{\circ} 40^{\prime} \mathrm{S}$ & $2.6^{\circ} \mathrm{S}$ & Maranhão, MA \\
\hline Avicennia germinans L. & A. germinans & Acanthaceae & Atafona & $21^{\circ} 37^{\prime} \mathrm{S}$ & $21.6^{\circ} \mathrm{S}$ & Rio de Janeiro, RJ \\
\hline Conocarpus erectus $\mathrm{L}$. & C. erectus & Combretaceae & Araruama & $22^{\circ} 55^{\prime} \mathrm{S}$ & $22.9^{\circ} \mathrm{S}$ & Rio de Janeiro, RJ \\
\hline Rhizophora mangle $\mathrm{L}$. & R. mangle & Rhizophoraceae & Praia do Sonho & $27^{\circ} 53^{\prime} \mathrm{S}$ & $27.8^{\circ} \mathrm{S}$ & Santa Catarina, SC \\
\hline Laguncularia racemosa Gaertn. & L. racemosa & Combretaceae & Laguna & $28^{\circ} 30^{\prime} \mathrm{S}$ & $28.5^{\circ} \mathrm{S}$ & Santa Catarina, SC \\
\hline Avicennia schaueriana Stapf. and Leech & A. schaueriana & Acanthaceae & Laguna & $28^{\circ} 30^{\prime} \mathrm{S}$ & $28.5^{\circ} \mathrm{S}$ & Santa Catarina, SC \\
\hline
\end{tabular}

The term "species limits" is defined as the spatial boundaries beyond which no living individuals of a given species occur. In this study, we use this term to describe the latitudinal limits of mangrove species across the Brazilian coastline in a southerly direction to provide an overview of the effects of climate on the species distribution.

From the literature, we found the species limits of seven mangrove shrubs/trees occurring in Brazil (see in: Lacerda et al. [29]; Table 1). The mangrove plant species have their northernmost limit beyond the Brazilian border, so our attention will focus on the southernmost limits of the species. The mangrove plant species limits are localized in three states: in Maranhão (MA) for Rhizophora racemosa and Rhizophora harrisonii (northeast limit); in Rio de Janeiro (RJ) for Avicennia germinans and Conocarpus erectus (southeast limit); and in Santa Catarina (SC) for Rhizophora mangle, Avicennia schaueriana and Laguncularia racemosa (south limit), the latter of which is also the limit of Brazilian mangroves as a whole. Those with wider distribution, reaching the limit of the Brazilian mangroves, are Avicennia schaueriana and Laguncularia racemosa, whereas Rhizophora mangle occurs up to $75 \mathrm{~km}$ north of that limit (Table 1).

\subsection{Environmental Geodatabase}

There are different techniques for mangrove mapping [30,31]. For example, at local scale, a very high-resolution image of QuickBird was used to evaluate the extent of mangrove forest area and in situ measurement was used to calibrate and estimate the "leaf area index" that enable us to detect the mangrove forest condition [32]. Moreover, McCarthy et al. [33] who were studying the coastal wetlands in Tampa Bay, Florida, USA used very high-resolution of the WorldView-2 images providing a better accuracy than previous studies that used low spatial resolution images. However, the small area coverage offered by very high-resolution images is a limitation when there is a need for a regional or global mapping [30] and for this reason, until now there is no global or regional mapping using very high-resolution images for mapping.

Currently, there are three main data sources of worldwide mangrove mapping, developed by Spalding et al. [7]; Spalding et al. [8]; and Giri et al. [9]. These three maps were compared by Ximenes [34], concluding that the Spalding et al. [7] map can be useful for global conservation projects because of the lighter data files due to the lower number of mangrove patches compared with the newest maps that facilitate geoprocessing analysis. The Spalding et al. [7] maps were hand-drawn by experts visually delineating mangroves using satellite images (such as (NOAA-AVHRR National Oceanic and Atmospheric Administration-Advanced Very High Resolution Radiometer), LANDSAT (Land Remote Sensing Satellite Program), SPOT (Satellite Pour l'Observation de la Terre) and ERS-1 (European Remote Sensing Satellite)) and their methods included small water bodies and barren land ecotones found inside the mangrove forests. In contrast, Giri et al. [9] mapped mangroves excluding water bodies and barren lands in order to keep only the forest, creating a more fragmented mangrove.

Figure 2 describes the detailed methodological procedures that will be explained in the next chapter. However, our line of inquiry and scientific questions are outlined in the introduction of this study. 


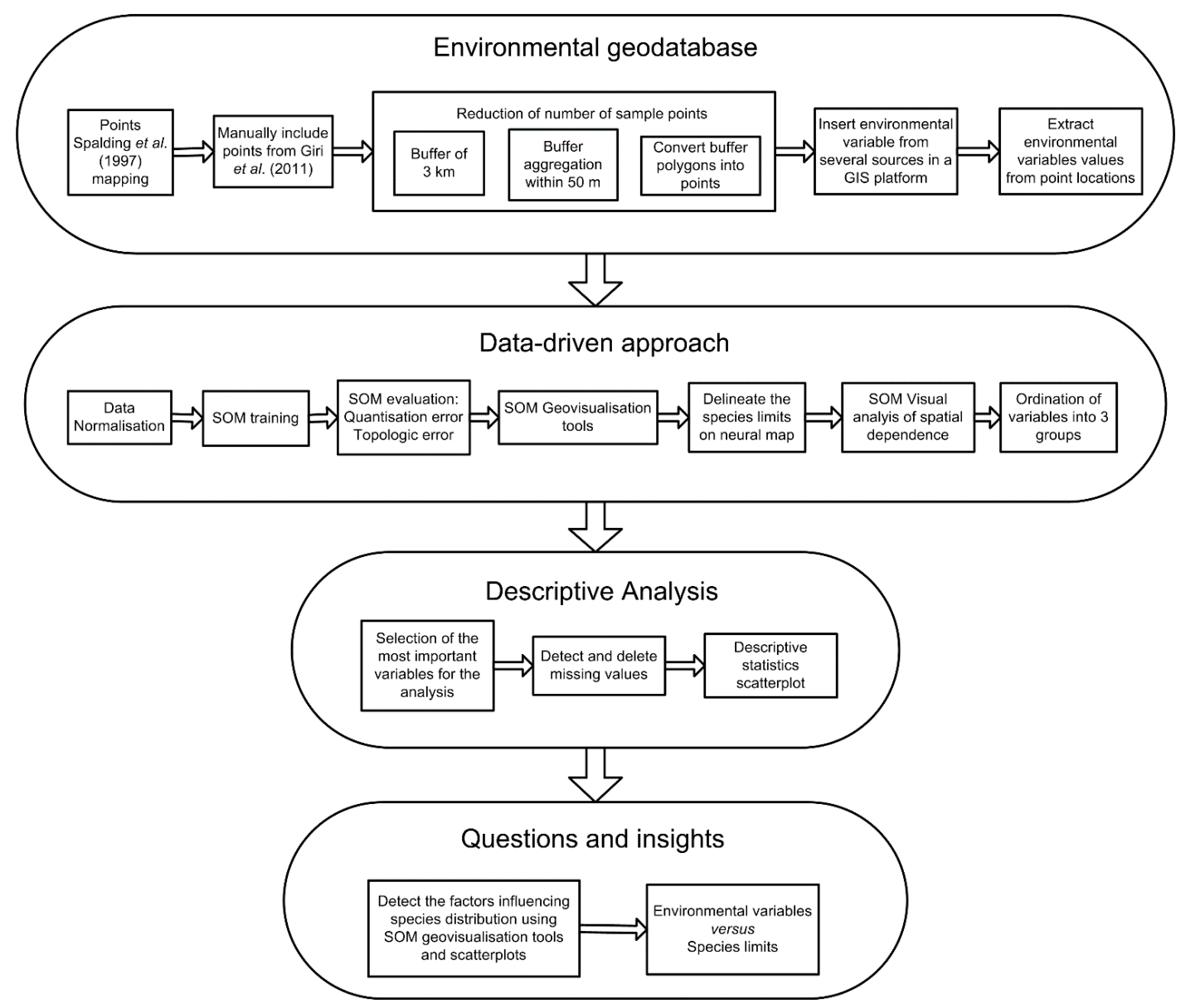

Figure 2. Methodological framework. Framework of the methodology applied in this study following four main steps. We refer to the text for methodological details.

For these reasons, the Spalding et al. [7] map was chosen to represent the location of mangrove forests, as in this study we needed to obtain at least one point for each mangrove location, rather than an accurate mangrove area. Furthermore, mangrove patches (=polygons) mapped by Spalding et al. [7] appear less fragmented, producing fewer cartographic point samples, which in turn correspond to the centroids of the mangrove patches, hence reducing redundant data. This fact can be explained by the low spatial resolution images used by Spalding et al. [7] that may exaggerate, exclude or reduce the mangrove areas, respectively by aggregating huge mangrove patches, or excluding small patches, that have a lower mangrove area size than the minimum area required for mapping. However, the Giri et al. [9] mangrove map was used to manually include mangroves that were not available in Spalding et al. [7].

Despite choosing a lower resolution mangrove map of Spalding et al. [7], the sample points were still numerous, and some redundant. The redundant sample points (i.e., sample points located too close to each other) were deleted, given that they represented the same information in the environmental database (see below). To reduce the number of samples and eliminate redundant data, we applied a $3 \mathrm{~km}$ buffer around the center of each sample point and aggregated all buffers located within a distance of $50 \mathrm{~m}$, creating a minimum distance between points of $6 \mathrm{~km}$.

Once the data had been cleaned, an environmental geodatabase was assembled in a GIS platform with 25 environmental variables including bioclimatic variables, sea surface temperature and salinity (Table 2) from several sources containing information from terrestrial and marine databases (see below). The bioclimatic variables were accessed from the Worldclim database and includes climate data for the 1950-2000 period, however, many records for the Brazilian Amazon are rather recent [4]. The 19 
bioclimatic variables are monthly temperature and rainfall values from a historical climate database that represents annual trends, seasonality and extreme climate values, where the quarter is a period of three months in a year [4]. These bioclimate variables have a spatial resolution of $c a .5 \mathrm{~km}$ at the equator (2.5 arc-minute) chosen to harmonize the scales of the variables from marine and terrestrial areas.

Table 2. List of variables used in this study composed of bioclimatic variables, sea surface temperature and sea salinity.

\begin{tabular}{|c|c|c|c|}
\hline Code & Unit & Resolution & Variables \\
\hline $\mathrm{BIO} 1$ & ${ }^{\circ} \mathrm{C}$ & \multirow{19}{*}{2.5 arc-minute } & Annual Mean Temperature \\
\hline $\mathrm{BIO} 2$ & ${ }^{\circ} \mathrm{C}$ & & $\begin{array}{l}\text { Mean Diurnal Range (Mean of monthly } \\
(\max \text { temp-min temp)) }\end{array}$ \\
\hline $\mathrm{BIO} 3$ & ${ }^{\circ} \mathrm{C}$ & & Isothermality $(\mathrm{BIO} 2 / \mathrm{BIO} 7)(\times 100)$ \\
\hline $\mathrm{BIO} 4$ & - & & Temperature Seasonality (standard deviation $\times 100$ ) \\
\hline BIO5 & ${ }^{\circ} \mathrm{C}$ & & Max Temperature of Warmest Month \\
\hline BIO6 & ${ }^{\circ} \mathrm{C}$ & & Min Temperature of Coldest Month \\
\hline BIO7 & ${ }^{\circ} \mathrm{C}$ & & Temperature Annual Range (BIO5-BIO6) \\
\hline BIO8 & ${ }^{\circ} \mathrm{C}$ & & Mean Temperature of Wettest Quarter \\
\hline BIO9 & ${ }^{\circ} \mathrm{C}$ & & Mean Temperature of Driest Quarter \\
\hline BIO10 & ${ }^{\circ} \mathrm{C}$ & & Mean Temperature of Warmest Quarter \\
\hline BIO11 & ${ }^{\circ} \mathrm{C}$ & & Mean Temperature of Coldest Quarter \\
\hline BIO12 & $\mathrm{mm}$ & & Annual Precipitation \\
\hline $\mathrm{BIO} 13$ & $\mathrm{~mm}$ & & Precipitation of Wettest Month \\
\hline BIO14 & $\mathrm{mm}$ & & Precipitation of Driest Month \\
\hline $\mathrm{BIO} 15$ & - & & Precipitation Seasonality (Coefficient of Variation) \\
\hline BIO16 & $\mathrm{mm}$ & & Precipitation of Wettest Quarter \\
\hline BIO17 & $\mathrm{mm}$ & & Precipitation of Driest Quarter \\
\hline $\mathrm{BIO} 18$ & $\mathrm{~mm}$ & & Precipitation of Warmest Quarter \\
\hline BIO19 & $\mathrm{mm}$ & & Precipitation of Coldest Quarter \\
\hline ARIDITY & - & \multirow{2}{*}{30 arc-second } & Aridity Index \\
\hline PET & $\mathrm{mm} /$ day & & Potential EvapoTranspiration \\
\hline SSTMIN & ${ }^{\circ} \mathrm{C}$ & \multirow{4}{*}{5 arc-minute } & Min Sea Surface Temperature \\
\hline SSTMEAN & ${ }^{\circ} \mathrm{C}$ & & Mean Sea Surface Temperature \\
\hline SSTMAX & ${ }^{\circ} \mathrm{C}$ & & Max Sea Surface Temperature \\
\hline SALINITY & PSU & & Sea salinity \\
\hline
\end{tabular}

N.B. $\min =$ minimum; $\max =$ maximum.

We highlight that Hijmans et al. [4] derived the "Min temperature of coldest month" or BIO6 from a multi-decade average of the minima of the coldest months, which is therefore comparable to the "mean temperature of the coldest month".

We also included two bioclimatic variables created by Zomer et al. [35] and Zomer et al. [36], the potential evapotranspiration (PET) and the aridity index, also using monthly climate data from the WorldClim database with a resolution of $1 \mathrm{~km}$ (30 arc-second). The PET is a measure of the ability of the atmosphere to remove water through evapotranspiration processes, whereas the aridity index can be used to quantify precipitation availability over atmospheric water demand [36,37]. In the Global-Aridity dataset, aridity index values increase with more humid conditions, and decrease with more arid conditions [37]. 
The sea surface temperature (SST) derivate and sea salinity were obtained from the BioOracle database, having a resolution of $c a .9 .2 \mathrm{~km}$ at the equator (five arc-minutes) [38]. The SST is the water surface temperature measured in the top most meter of the ocean water column using monthly observations with a temporal range from 2002 to 2009, and was obtained by the level-3 pre-processed satellite data from the Sensor Aqua-MODIS [6]. The SST major sources of error in the radiometric determination are sun glint, water vapor absorption in the atmosphere, trace gas absorption, etc. [39]. However, since calibration is done using in situ measurements, the SST data can be considered accurate to $\pm 0.4{ }^{\circ} \mathrm{C}[39]$.

The sea salinity variable with values in Practical Salinity Unit (PSU) indicates the dissolved salt content in the ocean. The data were collected by the World Ocean Database (WOD 2009) using DIVA interpolation of in situ measurements with a temporal range from 1961 to 2009 [5].

\subsection{Self-Organizing Maps (Data-Driven Approach)}

SOM is an artificial neural network based on competitive learning and non-supervised training [13,14]. It consists of organized units called neurons that are distributed in a regular low-dimensional grid where adjacent neurons are connected by a neighborhood relation, making what is often called as neural map [14,23]. The SOM and geovisualization tools were applied in this research to select groups of spatial dependent variables and to highlight environmental patterns that may influence the species distribution. The SOM parameters chosen for this work were: "Gaussian function neighborhood", "long training", batch algorithm, non-linear training, range transformation and the map neural size was defined according to the heuristics from Vesanto et al. [23] and the parameters will be further explained in the next paragraphs.

The SOM training is divided in three levels; competition, cooperation and learning [14]: first, random weights are distributed to each neuron of the neural map, then in each iteration (also called epoch) an Euclidian distance is calculated. Therefore, the shortest distance between the vector and its weight is called the winner neuron, also known as Best Matching Unit (BMU) (competition level) [14]. Next, the SOM algorithm identifies the closest neurons to the BMU and by Gaussian function local radius, the weights of excited neighborhood neurons are updated. A relatively large initial learning rate and neighborhood radius are used in the first phase to fine-tune the SOM approximately to the same space as the input data. In the second phase, both the learning rate and the neighborhood radius are small from the beginning, in order to achieve further fine-tuning of the SOM (cooperation level) $[14,23]$. Finally, the SOM converges based on learning rates which should decrease at each epoch (learning level) [14]. As clarified by Vesanto et al. [23], the SOM training algorithm moves the weight vectors so that they span across the data cloud and the map is organized in a way that neighboring neurons on the grid get similar weight vectors.

The batch training algorithm [14] displays all input vectors at once for the neural map before any adjustment is made. As a result the algorithm does not require a parameter of learning rate $\alpha(t)$ and does not need a random presentation of the input vectors $[14,40]$. In every epoch, the data set is partitioned according to the Voronoi regions, where each region corresponds to a unit on the neural map. Each input vector therefore belongs to a region in the neural map, in which it is closest. After the Voronoi regions have been defined, the average of the input vector is calculated from the centroid of each Voronoi region, thereby the weight vectors are updated [14,40].

To evaluate the SOM's results, two measurements of error were used: the mean quantization error and the topographic error [14]. The mean quantization error is the average distance between each data vector and its BMU, and thus measures map resolution. The topographic error represents the proportion of all data vectors for which 1st and 2nd BMU's are not adjacent, and is used for the measurement of topology preservation [14]. For this work, we used three geovisualization tools called: SOM component plan, D-matrix and SOM Labels and SOM Principal Component Analysis (SOM-PCA) [23]. 
The SOM component plan shows the attribute patterns formed by high and low values in a neural map where the relationship between variables can be identified by visual analysis [14] or automatically detected by the SOM-PCA that orders the SOM component planes by the similarity of patterns [23,41].

The Unified distance matrix (U-matrix) [42] is able to detect the topological relationship between neurons. It is based on the combination of variables used in that specific data set, measuring the degree of similarity by the Euclidean distance between adjacent neuron weight vectors where high and low distance values correspond to dissimilar and similar neighboring neurons, respectively [42]. For this work, we used the Distance Matrix (D-matrix) that is also called SOM cluster, because similar neurons can be seen as a cluster and dissimilar neurons as a boundary between the clusters [14]. Areas with similar colors are close to each other in the input space [43]. The D-matrix is an averaged version of the U-matrix that enhances the visibility of dissimilar areas in the neural map [43].

The SOM label map shows the geographical localization of the Brazilian states and the frequency of the samples in each neuron brought the spatial information to the D-matrix when we overlapped it. Samples in the same neuron indicate mangrove locations with similar environmental factors. Occasionally, more than one sample fits into a single neuron, mainly because the samples are extremely similar or due to the size of the neural map [44]. Analyzing the SOM label map together with component planes provides us an overview of the environmental factors that change according to the geographical space. The SOM methods were carried out using the SOM Toolbox in MATLAB software [23,45].

\subsection{Descriptive Analysis}

We used the SOM-PCA as a data-driven approach to assist a pre-selection of variables' group and two variables of each group were further analyzed. Scatterplots, cartographical and cartogram maps were computed and analyzed for the most important variables that are often used to determine structure, composition, abundance and distribution of mangroves [46,47].

Because the species richness declines from the north to the south (Figure 1 and Table 1), the latitude was used in the scatterplots as a dependent variable versus environmental factors as independent variables. This provides a better understanding of the environmental influence on species distribution. In addition, we spatialized cartogram maps, which are abstract maps distorted proportionally by the values of the selected variable [48] to overstate the contrast between regions with low and high values. To create the cartogram maps, we used the GeoDa software [49]; and all geoprocessing procedures and map building was done using ArcGIS 10 Desktop [50].

The missing values were excluded, but we also made sure that the deleted samples were surrounded by other point samples in their neighborhood. In this sense, we kept important locations, for instance at the distribution limits of mangroves or in isolated mangrove patches.

\section{Results}

\subsection{Self-Organizing Maps}

After the data cleaning process, the samples were reduced from 900 to 390, representing $43 \%$ of the total. Nevertheless, the remaining samples were well spread out, representing the entire distribution of Brazilian mangrove. The resulting neural map size had 98 neurons with dimensions of $14 \times 7$. The rough training phase had 12 epochs and fine tuning phase 44 epochs which generates a low quantization error (0.28) and topological error (0.01). Here, we divide 25 variables in three groups showing the similarities and inverse correlations between variables based on the result of the SOM-PCA component planes. Group 1 consists of variables of air and sea surface temperature that approximately follow a latitudinal gradient. In this group, we only found one "precipitation" variable, which can, however, be linked to "temperature", as it is the precipitation of the "warmest" quarter of the year. Group 2 is represented by the variables of air temperature, precipitation and evapotranspiration. There is also a correlation between Groups 1 and 2, which is, however, less strong 
than their within-group correlations. Group 3 is represented by the variables of precipitation, aridity and salinity (Figure 3).
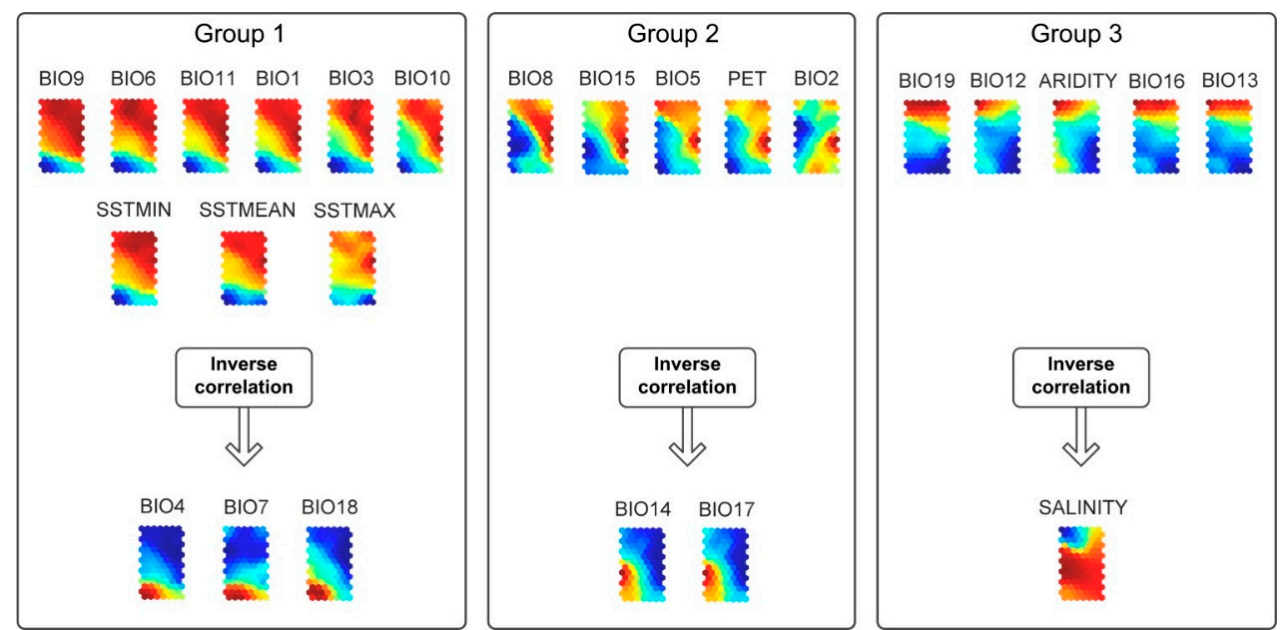

Figure 3. SOM Component planes. The component planes organized in three groups according to correlated components. High values are in red, intermediated values in yellow and green, and low values in dark blue.

Figure 4 provides useful information regarding the spatial location of states, the environmental dissimilarities within each and between states according to the D-Matrix and the lines roughly represent the distribution of species. To better understand these "climate barriers" in the D-Matrix neural map (Figure 4), it is necessary to further interpret the component planes of the variables (Figure 3). Keeping in mind the lines showed in the D-Matrix (Figure 4) and the component planes of the variables (Figure 3) some insights come up in order to understand which variables can provide explanations about species distribution. The patterns of low and high values in the component planes easily match some limits of the species distribution and we will expose some observations and insights based on these results.

The species $R$. racemosa and $R$. harrisonii are distributed where we can find high and intermediate values of precipitation and just after their limits are the low values (Figures 3 and 4 ) indicating that these species may be geographically limited by rainfall patterns, composed by the variables of Group 3, but also Group 2. By contrast, the species A. germinans, C. erectus, $R$. mangle, A. schaueriana and $L$. racemosa are likely more affected by temperature than by precipitation where their limits match with the low values of temperature, composed by the variables of Group 1 . The high salinity value is mainly homogeneous over the mangrove areas, except by the low values in the north region. Therefore, it does not give us possible feedback or explanation about the species distribution. 


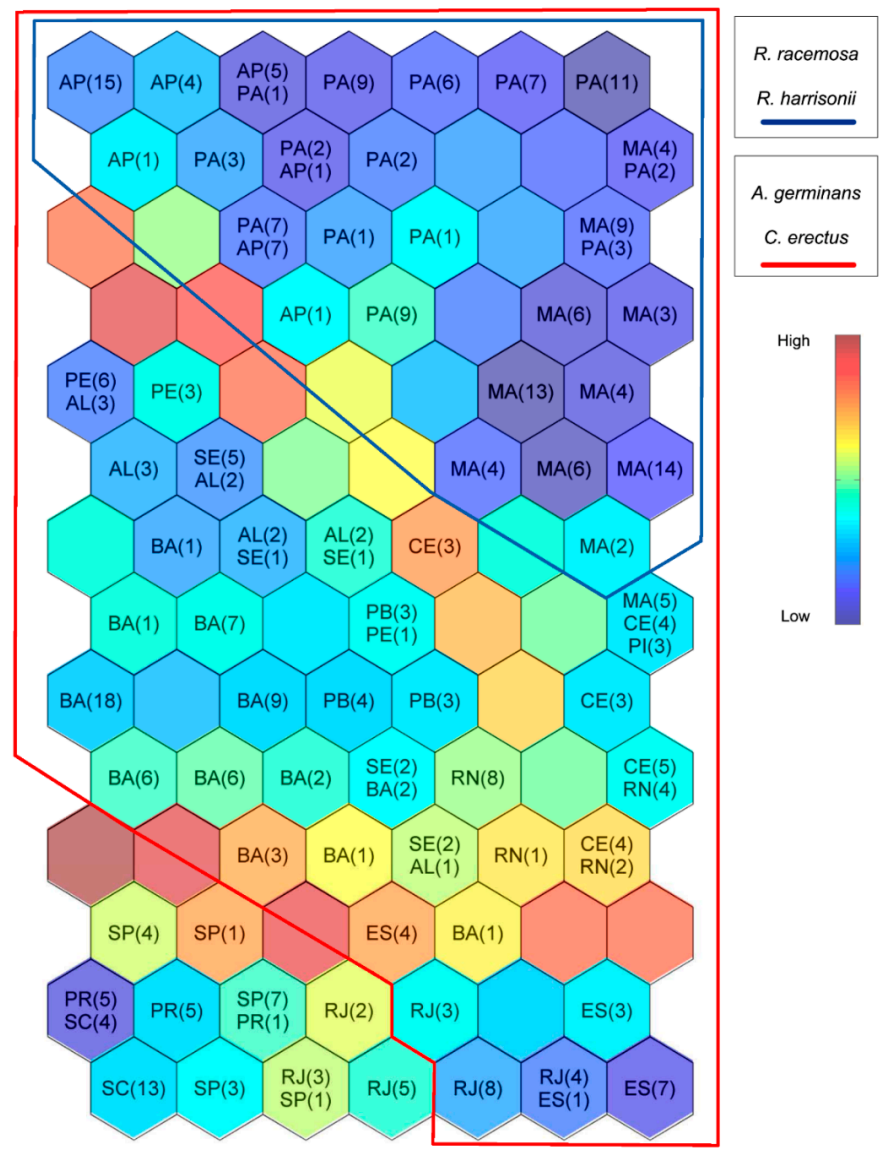

Figure 4. SOM labels and D-Matrix overlapped with species distribution. High values are boundaries between clusters and indicate high dissimilarities. Low values can be considered as a cluster, with more similarity and homogeneity. Brazilian States demarcate the localization on the neural map and the numbers indicate their frequency in each neuron. This figure represents the geographical location of samples that have a relation with component planes in Figure 3. At the top of the map are the northern states, in the middle the northeastern states, further down and to the right and center are the southeastern states and the lower left side shows the southern states where the mangrove reaches its limits. The red and blue polygons indicate the range of the mangrove species that are found along a section of the Brazilian coastline. Indicating the species that are found along the entire coastline would create a polygon around the entire neural map (not shown).

\subsection{Environmental Description}

In our database, we found 56 missing values for the PET and Aridity, in which were removed to compute the statistics because scatterplots cannot handle missing values, like the SOM methods can. A total of 334 sample points were used for the descriptive analyses focusing on at least two important variables from each group, showed on Figure 3, which are: BIO6, SSTMIN (Group 1); PET and BIO17 (Group 2); BIO12 and aridity index (Group 3). In the next section, we will give further explanation of these variables.

\subsection{Air Temperature and Sea Surface Temperature}

We found little difference in the minimum temperature of the coldest month (BIO6) and quarter (BIO11) for the species southernmost limits highlighting that A. schaueriana and L. racemosa reach the same distribution limit in Laguna (SC), but the limit of $R$. mangle is about $75 \mathrm{~km}$ more to the north. Despite the fact that BIO6 roughly follows the latitudinal gradient $\left(\mathrm{R}^{2}=0.87\right)$, our findings indicate that the minimum temperature of the coldest month found for all mangroves in Brazil is $10.4{ }^{\circ} \mathrm{C}$ 
located around $90 \mathrm{~km}$ to the north of the southernmost $R$. mangle limit in the estuary of the Camboriu river (Balneário Camboriú-SC) at Santa Catarina (Figure 5a). At the latitudinal limit of mangroves in Laguna, approximately $160 \mathrm{~km}$ more to the south, we found a minimum temperature of $12.5^{\circ} \mathrm{C}$, which is $2.1^{\circ} \mathrm{C}$ higher than the minimum found in Camboriú. Therefore, we found the lowest values of the minimum air temperature of the coldest month for mangroves with lower values than what we found in the mangroves southernmost limit in the coastal mesoregion of Vale do Itajaí (Figure 5a).

(a)

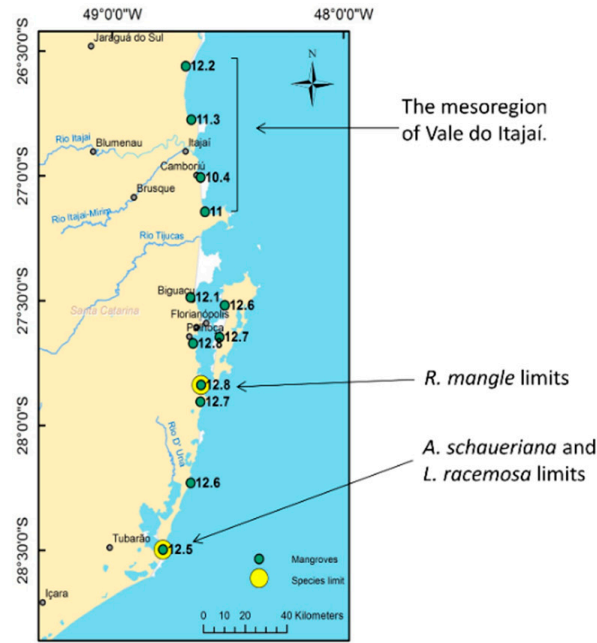

(c)

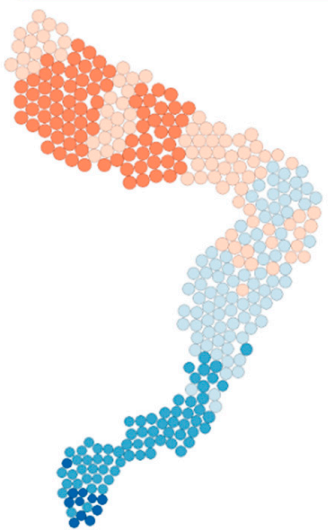

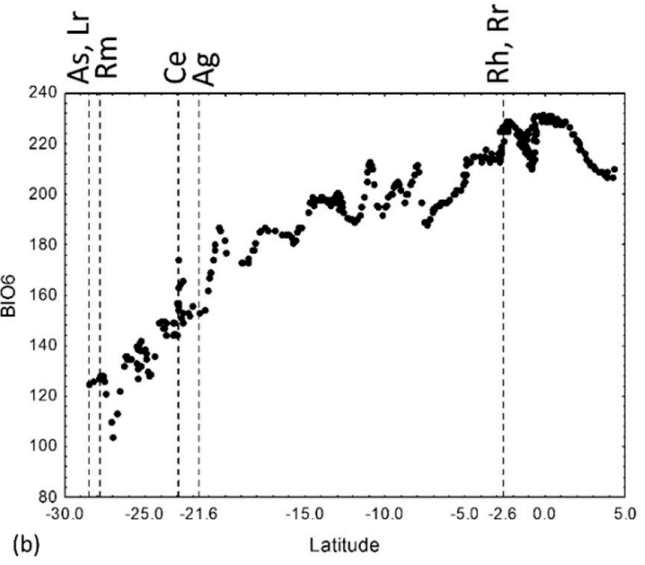

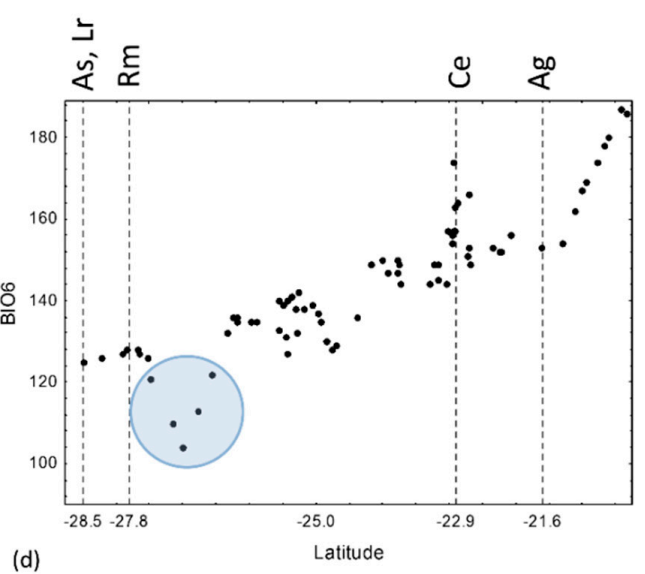

Figure 5. Detailed description of the Min temperature of coldest month (BIO6) $\left({ }^{\circ} \mathrm{C} \times 10\right)$ for mangroves in Brazil. (a) Detailed map of the south limits with their BIO6 values for each location of mangroves; (b) Scatterplot $(n=334)$ representing the BIO6 by latitude in decimal degree superimposed on species distribution limits of (vertical dashed lines from the right to the left) $R$. racemosa (Rr) and $R$. harrisonii $(\mathrm{Rh})$

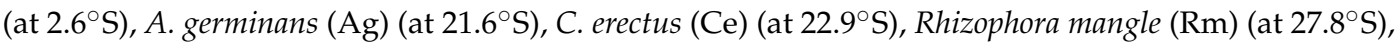
and finally A. schaueriana (As) and L. racemosa (Lr) (together at $28.5^{\circ} \mathrm{S}$ ). The vertical dashed lines from the right to the left can therefore be seen as the increasing richness of mangrove trees species; (c) Cartogram map distorted by the high and low values of BIO6. Each circle represents a mangrove sample point location (however distorted), the circle size overstates the value of the variable (here BIO 6), and the circle color represents the lower outliers, the lower quartile, the inter-quartile range (split into an upper and lower part), the upper quartile and the upper outliers, in exactly the same way as a Box and Whisker plot. The legend also shows the number of samples per color between brackets; (d) Scatterplot of BIO6 with a detailed zoom on the surrounding of the southernmost species distribution limits (vertical dashed lines of the species limits) and the blue circle indicates the mesoregion of Vale do Itajaí with the lowest values of BIO6 in the Brazilian mangroves.

The SSTMIN follows the latitude with a gradual decline in direction to higher latitudes $\left(\mathrm{R}^{2}=0.86\right)$ (Figure 6). Contrary to BIO6 (Figure 5), the lowest SSTMIN value is in Laguna $\left(17^{\circ} \mathrm{C}\right)$ and in the limits 
of R. mangle is $1^{\circ} \mathrm{C}$ higher $\left(18^{\circ} \mathrm{C}\right.$ ) (Figure $6 \mathrm{c}$ and Table 3). From $2.6^{\circ} \mathrm{S}$ to $21.6^{\circ} \mathrm{S}$ of latitude, the SSTMIN decline gradually from $29^{\circ} \mathrm{C}$ to $23^{\circ} \mathrm{C}$, however, it has a dramatic decline after the latitude $21.6^{\circ} \mathrm{S}$ to $28.5^{\circ} \mathrm{S}$, with SSTMIN from $23^{\circ} \mathrm{C}$ to $17^{\circ} \mathrm{C}$ in a southerly direction (Figure $6 \mathrm{~b}$ ).

(a)

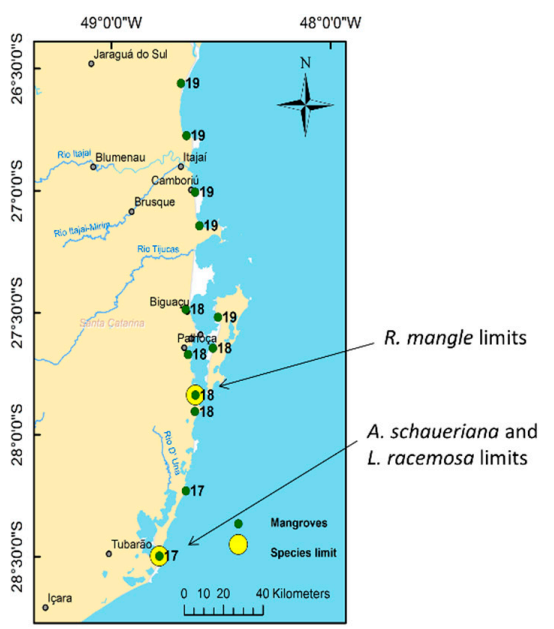

(c)

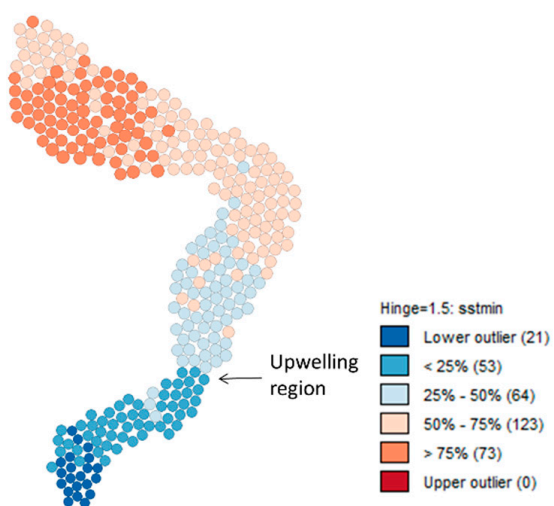

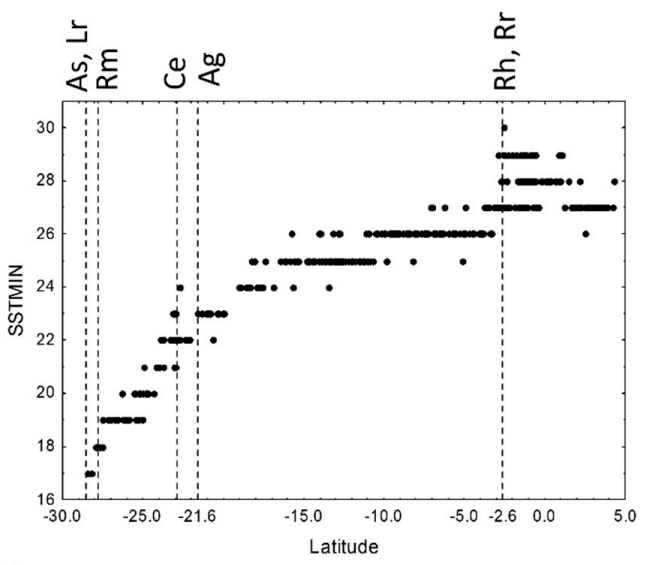

(b)

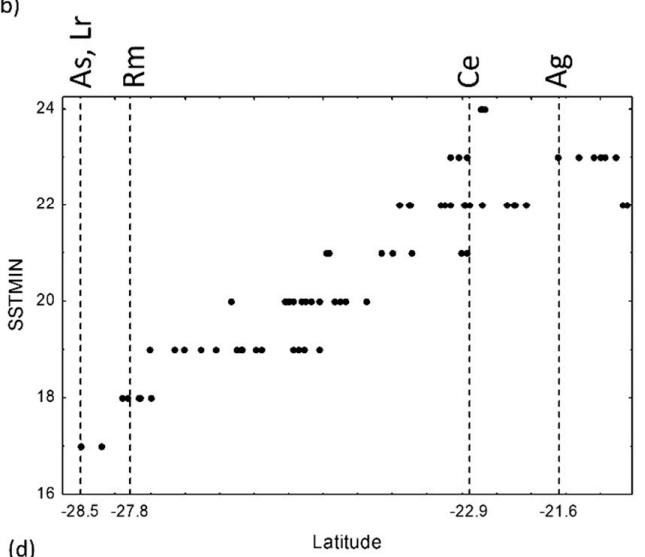

Figure 6. Detailed description of the Min sea surface temperature (SSTMIN) $\left({ }^{\circ} \mathrm{C}\right)$ for mangroves in Brazil. (a) Detailed map of the south limits with their SSTMIN values for each location of mangroves; (b) Scatterplot $(n=334)$ representing the SSTMIN by latitude in decimal degree superimposed on species distribution limits (vertical dashed lines); (c) Cartogram map distorted by the high and low values of SSTMIN; (d) Scatterplot of SSTMIN with a detailed zoom of the surrounding area of the southernmost species distribution limits (vertical dashed lines of the species limits). Refer to Figure 5 for further explanations.

Table 3. An overview of values of air temperature derivate and sea surface temperature derivate according to punctual values at latitudinal species limits and their species richness values for each limit.

\begin{tabular}{ccccccccc}
\hline Species & Latitude & Richness & BIO1 & BIO6 & BIO11 & SSTMIN & SSTMEAN & SSTMAX \\
\hline $\begin{array}{c}\text { R. racemosa } \\
\text { and } \text { R. harrisonii }\end{array}$ & $2.6^{\circ} \mathrm{S}$ & 7 & 27.3 & 22.1 & 26.7 & 27 & 29 & 29 \\
$\begin{array}{c}\text { A. germinans } \\
\text { C. erectus }\end{array}$ & $21.6^{\circ} \mathrm{S}$ & 5 & 23.0 & 15.3 & 20.7 & 23 & 26 & 28 \\
$\quad$ R. mangle & $22.9^{\circ} \mathrm{S}$ & 4 & 23.0 & 17.4 & 20.9 & 22 & 25 & 27 \\
A. schaueriana & $27.8^{\circ} \mathrm{S}$ & 3 & 20.0 & 12.8 & 16.4 & 18 & 22 & 22 \\
and L. racemosa & $28.5^{\circ} \mathrm{S}$ & 2 & 19.9 & 12.5 & 16.3 & 17 & 27 \\
\hline
\end{tabular}

There is no difference between the values of SSTMEAN in the two southern limits $\left(22^{\circ} \mathrm{C}\right)$ and the minimum value of SSTMAX located at $R$. mangle limit, not in the extreme south. However, the SSTMIN is the only variable that demonstrates species' richness, even though these values are relatively close between the two successive species limits (Table 3). 


\subsection{Annual Precipitation, PET and the Precipitation of the Driest Quarter}

The "Annual precipitation" reaches a peak at $3.791 \mathrm{~mm}$ in Nazaré, Amapá followed by a dramatic fall until the lowest value of $600 \mathrm{~mm}$ in Macau, in Rio Grande do Norte state close to the border with Ceará (Figure 7b). The next lowest value is in the surroundings of Arraial do Cabo in Rio de Janeiro with $870 \mathrm{~mm}$. However, we also found lowest values of BIO12 in some sites in Ceará (937 mm), Bahia (990 mm) and Espírito Santo (1003 mm).

(a)

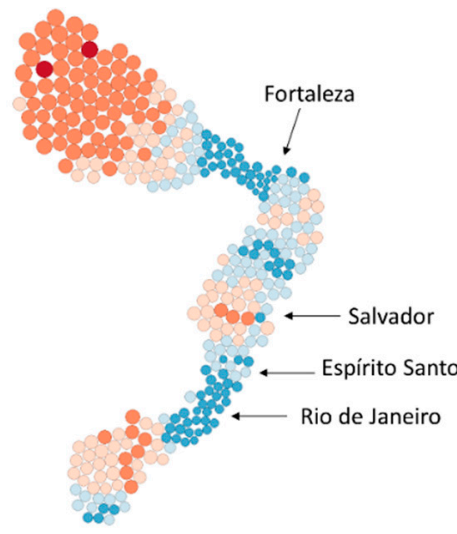

(c)

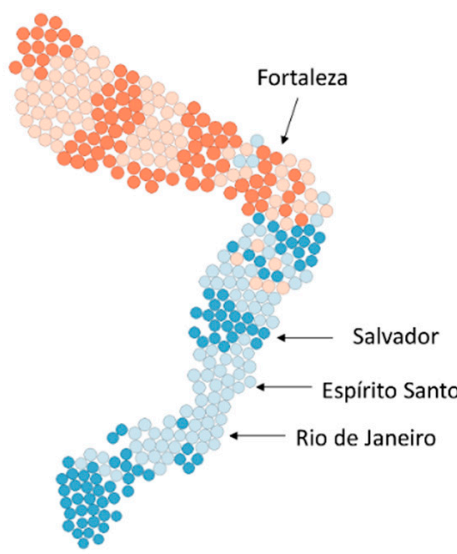

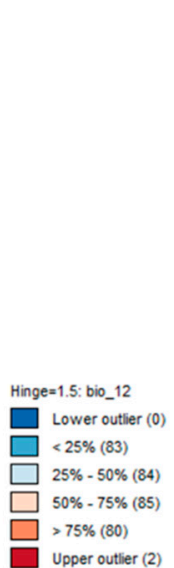

(b)
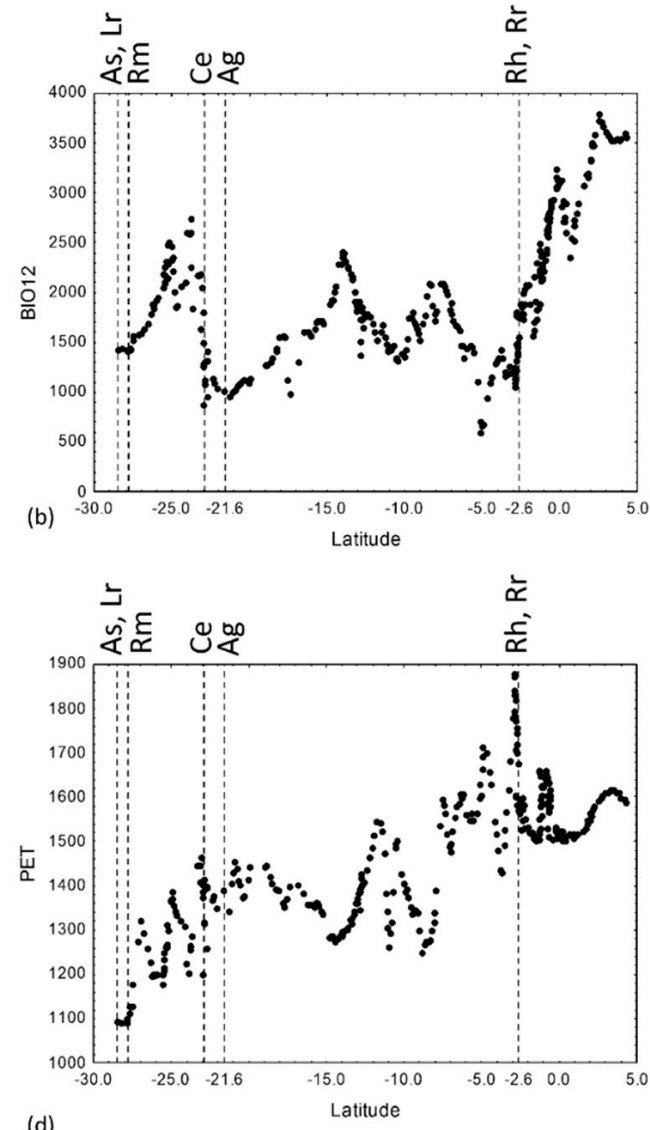

(d)

Figure 7. Detailed description of the Annual Precipitation (BIO12) and Potential Evapo-Transpiration (PET) for mangroves in Brazil. (a) The cartogram map distorted by the high and low values of BIO12; (b) Scatterplot $(n=334)$ representing the BIO12 by latitude in decimal degree superimposed on species distribution limits (vertical dashed lines); (c) Cartogram map distorted by the high and low values of PET; (d) Scatterplot $(n=334)$ representing the PET by latitude in decimal degree superimposed on species distribution limits. Refer to Figure 5 for further explanations.

The cartogram map (Figure 7a,c) enhances the spatial fluctuations of values of BIO12 and PET along the Brazilian coast while the highest values of PET are concentrated in the north and part of the northeast regions, the BIO12 present high and low values in all Brazilian regions (Figure 7).

The driest regions of Brazil's mangroves are located in the northeast states of Piauí, Ceará and Rio Grande do Norte (Figure 8a). After this region the precipitation of the driest quarter increases to the south, and reaches a peak of $466 \mathrm{~mm}$ in Camamu/Maraú in Bahia that has a remarkable and high amount of precipitation during the driest periods in comparison with other regions (Figure 8b,c). The cartogram of the precipitation of the driest quarter shows a strong restriction of precipitation during the driest season in the limits of the two species of Rhizophora (Figure 8c). 

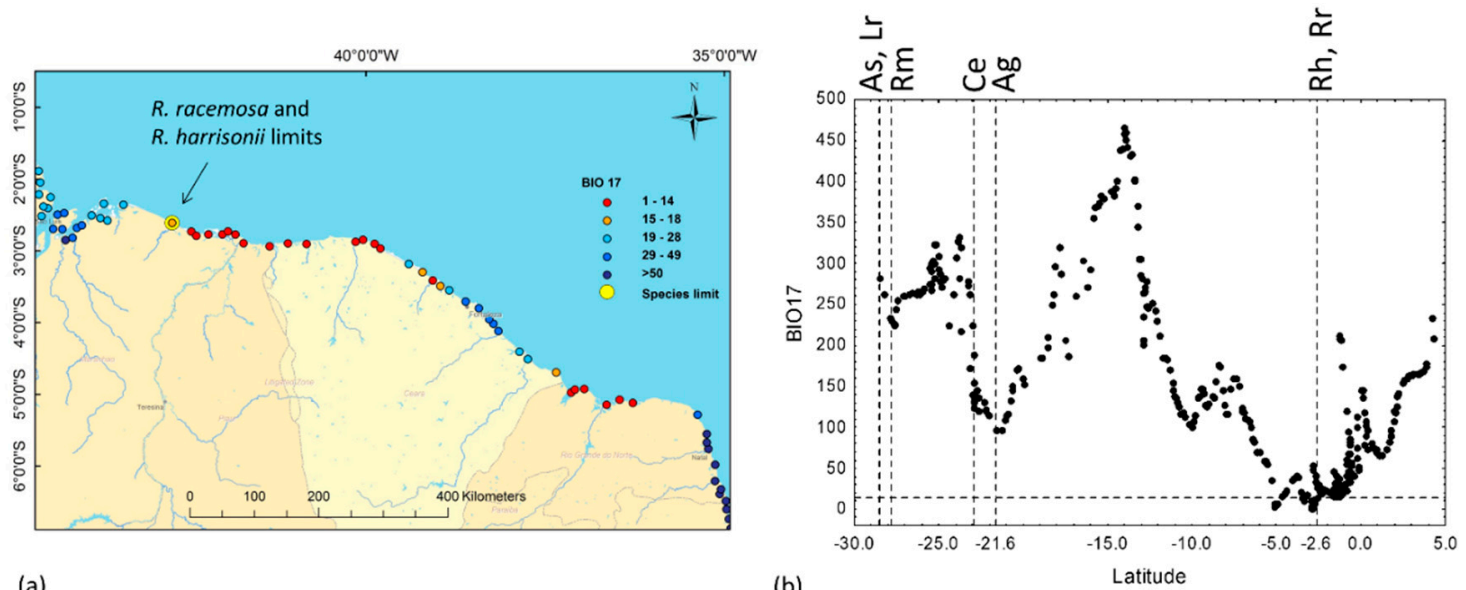

(a)
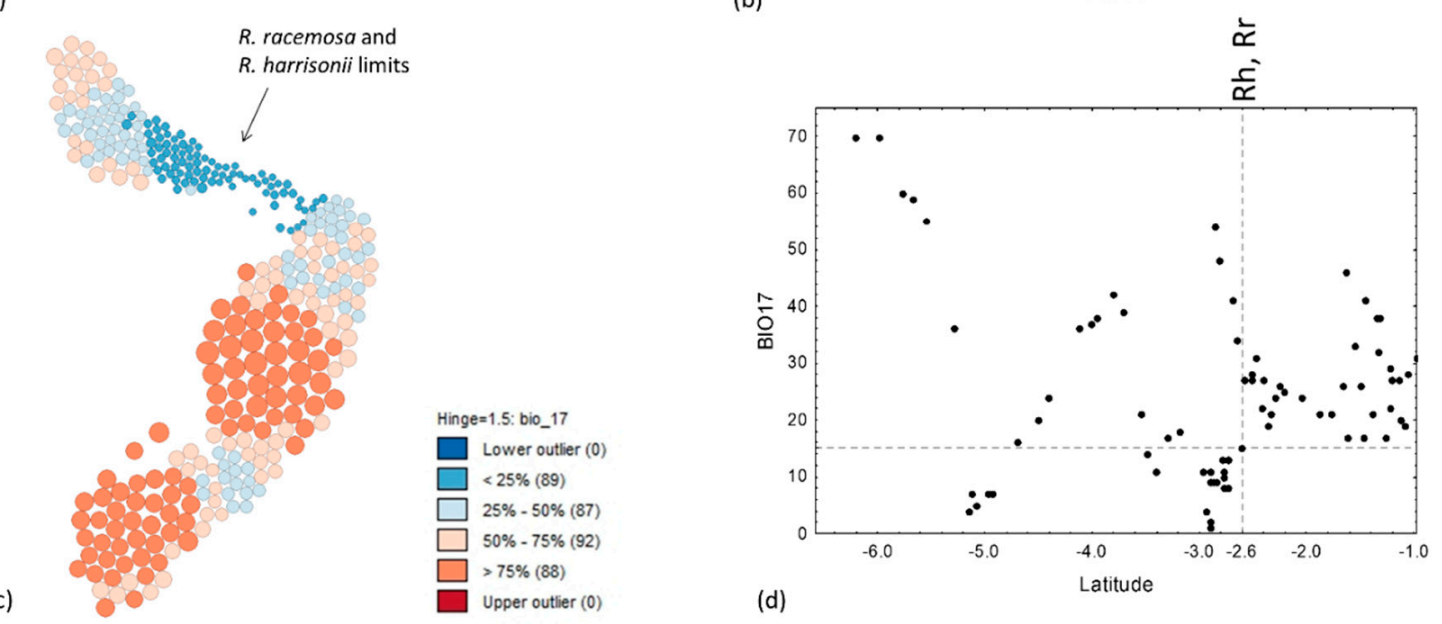

Figure 8. Detailed description of the Precipitation of the driest quarter (BIO17) for mangroves in Brazil. (a) Detailed map of the northeast limits with their BIO17 values for each location of mangroves; (b) Scatterplot $(n=334)$ representing the BIO17 by latitude in decimal degree superimposed on species distribution limits of (vertical dashed lines); (c) Cartogram map distorted by the high and low values of BIO17; (d) Scatterplot of BIO17 with a detailed zoom on the surrounding area of the northeast species distribution limits (vertical dashed lines of the species limits). The horizontal dashed lines in the BIO17 scatterplots indicate a barrier of $<15 \mathrm{~mm}$ of precipitation for the Rhizophora species' northeast limits. Refer to Figure 5 for further explanations.

The scatterplot does not show the precise value of the BIO17 and Aridity at and after the limit (Figures $8 \mathrm{~b}$ and $9 \mathrm{~b}$ ) due to the little latitudinal variation in the limits of $R$. racemosa and $R$. harrisonii (Figure $8 b$ ). For this reason, we spatialized the distribution of these variables in a map that can better reveal the influence of precipitation for the species limits. For instance, the two Rhizophora species are not distributed in areas with the "Precipitation of driest quarter" $<15 \mathrm{~mm}$ (Figure 8d), Aridity $<0.9$ index (Figure 9d). 


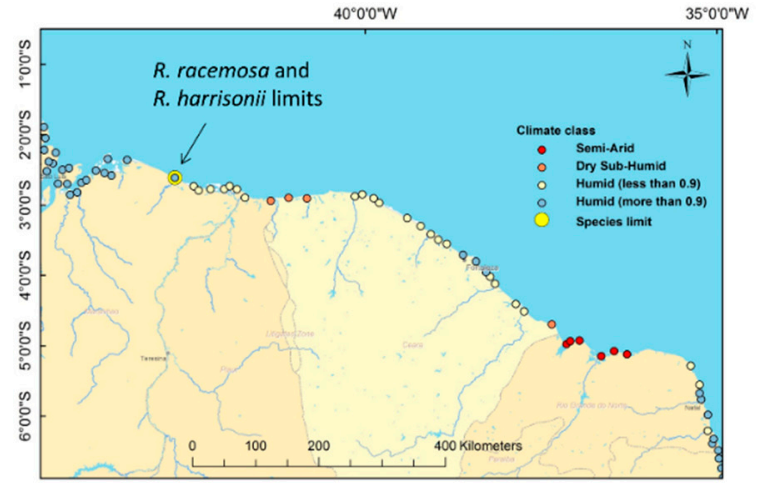

(a)

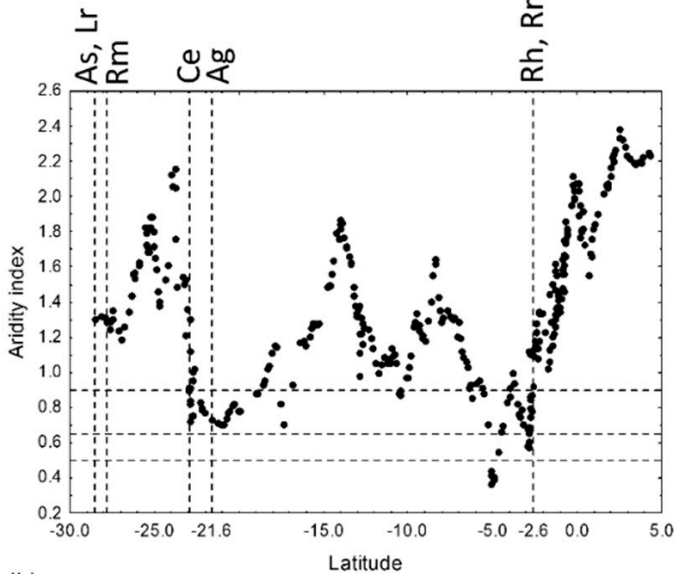

(b)

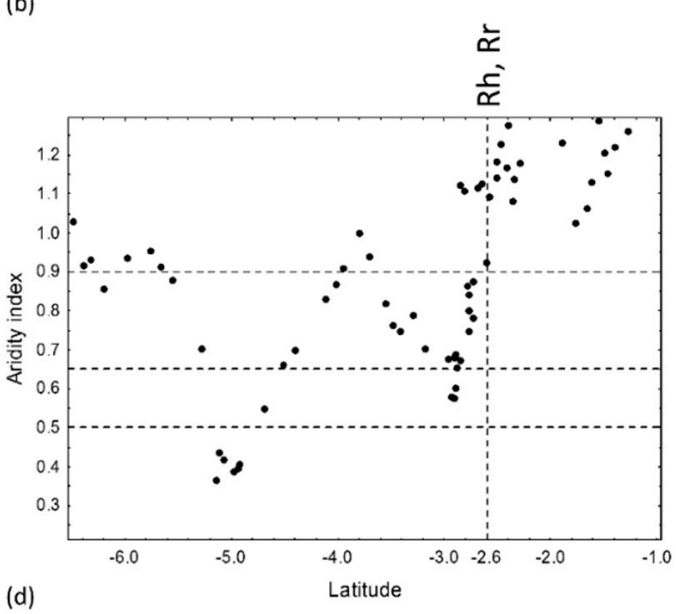

Figure 9. Detailed description of the Aridity index for mangroves in Brazil. (a) Detail spatial distribution map of the northeast limits with their Aridity values for each location of mangroves; (b) Scatterplot $(n=334)$ representing the aridity by latitude in decimal degree superimposed on species distribution limits of (vertical dashed lines); (c) Cartogram map distorted by the high and low values of aridity index; (d) Scatterplot of aridity with a detailed zoom on the surrounding of the northeast species distribution limits (vertical dashed lines of the species limits). The horizontal dashed lines in the aridity index indicate the climate class (0.2-0.5-Semi-Arid; 0.5-0.65-Dry Sub-humid; >0.65-Humid) [3], and we included an additional dashed line at aridity index 0.9 , because as shown in (a) the two species of Rhizophora reach their southernmost limit around that value. Refer to Figure 5 for further explanations.

Brazilian mangroves are distributed mostly in humid areas ( $>0.65$ Aridity index) with few exceptions of dry sub-humid areas in the border of Piauí and Ceará and semi-arid areas located in Rio Grande do Norte (Figure 9b) and just beyond the limits of R. racemosa and R. harrisonii (Figure 9a). We used a dashed line to indicate the humid areas with 0.9 of aridity index, because it seemed that a limit for these two species of Rhizophora genus (Figure 9b,d) and the detailed map (Figure 9a) help highlight the geographical space where their distribution is restricted to $>0.9$ of the aridity index.

In the $R$. racemosa and $R$. harrisonii limits, Table 4 shows that the annual precipitation is favorable (1549 mm), however, the precipitation of the warmest quarter, and the driest quarter and month is low, at $16 \mathrm{~mm}, 15 \mathrm{~mm}$ and $5 \mathrm{~mm}$, respectively. 
Table 4. An overview precipitation derivate and aridity according to punctual information at latitudinal species limits and their species richness for each limit.

\begin{tabular}{cccccccc}
\hline Species & Latitude & Richness & BIO12 & BIO14 & BIO17 & BIO18 & Aridity \\
\hline R. racemosa and R. harrisonii & $2.6^{\circ} \mathrm{S}$ & 7 & 1549 & 5 & 15 & 16 & 0.92 \\
A. germinans & $21.6^{\circ} \mathrm{S}$ & 5 & 1014 & 27 & 98 & 329 & 0.73 \\
C. erectus & $22.9^{\circ} \mathrm{S}$ & 4 & 870 & 39 & 125 & 242 & 0.72 \\
R. mangle & $27.8^{\circ} \mathrm{S}$ & 3 & 1420 & 72 & 230 & 535 & 1.29 \\
A. schaueriana and L. racemosa & $28.5^{\circ} \mathrm{S}$ & 2 & 1431 & 89 & 282 & 434 & 1.30 \\
\hline
\end{tabular}

\section{Discussion}

\subsection{Explaining the Species Limits}

As temperature is correlated with latitude, a similar sequence of species loss with increasing latitude should be discernible [46,51]. Where mangroves are not limited by aridity or precipitation, temperature is the major factor in reducing number of species correlated with latitude [51-53]. However, the opposite is also true: when the temperature is suitable for mangroves, the availability of precipitation may have a stronger influence on certain mangrove species' distributions [51]. Several reports have suggested that the distribution of mangroves on western coasts of southern continents is generally more limited by aridity than by temperature [51-53]. Having these facts in mind, and based on our results, we can delineate a deeper hypothesis for the species distribution along the Brazilian coast.

R. racemosa and $R$. harrisonii species are not distributed in areas with low precipitation $<15 \mathrm{~mm}$ in a drier quarter or $<5 \mathrm{~mm}$ in a drier month and $<0.9$ of aridity index. For these two species, temperature is not likely to be a limiting factor for the distribution of these congeners in Brazil because the "Mean temperature of the warmest quarter" is $28.7^{\circ} \mathrm{C}$ in Camocim (CE), and the "Min temperature of the coldest month" is also $>20^{\circ} \mathrm{C}$, which is still suitable for these species. A previous experimental study in Costa Rica confirmed that $R$. racemosa is inhibiting in its landward establishment because of drought and high soil salinities [54]. However, until now there are few studies about these two Rhizophora species, especially in Brazil.

According to the updated climate classification of Köppen-Geiger [55] in species limits of R. racemosa and $R$. harrisonii are described as equatorial savanna with dry winter (Aw), but $c a .350 \mathrm{~km}$ south of these species limits the classification changes to equatorial savanna with dry summer (As), and ca. $670 \mathrm{~km}$ after the limits is classified as arid zones of hot steppe or steppe climate (BSh). However, in this coastal stretch of $350 \mathrm{~km}$, we found the humid ( $<0.9$ aridity index) and dry sub-humid climate classes, and after ca. $670 \mathrm{~km}$ we found semi-arid classes are south of Rhizophora limits, based on UNEP [37] aridity index classification.

In Cabo Frio, the strongest of about seven coastal upwelling areas along the southeastern and southern coast of Brazil is found [56], and this coincides with the southernmost distribution limit of A. germinans and C. erectus (Table 1). This intense upwelling has been recognized as an important biogeographic barrier for the distribution of several algal taxa along the Brazilian coast [57-59]. Weather/climate patterns can be influenced by upwelling, which reduces precipitation and moderates temperatures [60].

At the species limits of $A$. germinans and $C$. erectus, we found the annual precipitation to vary between 870 and $1014 \mathrm{~mm}$, which is one of the driest regions of the southeast and south of Brazil. Yet $A$. germinans and $C$. erectus are known to survive in more arid regions in the northeast $(<600$ $\mathrm{mm}$ of Annual precipitation). However, under upwelling conditions, sea surface temperature can reach as low as $13{ }^{\circ} \mathrm{C}$ [61] or $18{ }^{\circ} \mathrm{C}$ [62], which is below or close to the temperature limit known to inhibit propagule germination in the mangrove A. germinans [63]. Although also non-upwelling conditions with temperatures over $21^{\circ} \mathrm{C}$ [61] exist, the upwelling conditions might also be a barrier for A. germinans and C. erectus and should be further investigated. 
Our results suggest that at the southernmost limits of mangroves the air temperature is not as low as that found at lower latitudes such as in the Mesoregion Vale do Itajaí (Figure 5). This is exemplified by the min temperature of the coldest month (BIO6 $=10.4^{\circ} \mathrm{C}$ ) in Camboriú (Figure 5), ca. $90 \mathrm{~km}$ more north than the $R$. mangle limit (where BIO6 $=12.8^{\circ} \mathrm{C}$ ). However, $R$. mangle does not grow in Camboriú [64] and its distribution is therefore more discontinuous than that reported by other authors $[7,8]$. The same discontinuity was also reported for other mangrove species elsewhere in the world [65]. However, in Brava Beach in Itajaí $\left(\mathrm{BIO} 6=11.3^{\circ} \mathrm{C}\right)$, just about $10 \mathrm{~km}$ north of Camboriú, there is a record of $R$. mangle [64], which leads us to question whether this is due to physiological or dispersal limitations.

Firstly, one could argue that a physiological limitation at temperatures below $11^{\circ} \mathrm{C}$ exist, but experiments in Florida with $R$. mangle has demonstrated survival of this species at temperatures of $4{ }^{\circ} \mathrm{C}$ [66]. However, the natural population of R. mangle in Florida (USA) at Ponce Inlet grows under lower temperatures than in Brazilian mangroves (average minimum $=9.5^{\circ} \mathrm{C}$ ), and experiences severe freezes every eight years. [66], hence, these findings may not be extrapolated to mangroves in Brazil. To our knowledge, there are no data available to support any straightforward plant physiological limitation marking a limit between roughly 10 and $11^{\circ} \mathrm{C}$.

Secondly, dispersal limitations may be linked to the water current, the wind or physical barriers affecting large nautohydrochorous propagules but not small ones since A. schaueriana apparently has no restriction in establishing at Camboriú. Bias in the metadata sets available may be a possibility (see also below), but further research is needed to elucidate the absence of $R$. mangle in Camboriú. However, also here, there is no physiological or dispersal evidence at hand to explain this.

In contrast to Quisthoudt et al. [67] and to what we expected, in Brazil we did not find a clear difference for the minimum air temperature of the coldest month and quarter in the limits of $R$. mangle, A. schaueriana and L. racemosa.

Further research should concentrate on unveiling the importance of temperature variables that give differences between the distribution limit of the southernmost species, such as SSTMIN (Table 3).

\subsection{Comparison Climate Databases}

We identified differential maximum and minimum extreme values organized in a table (Table 5) comparing our results with those of Schaeffer-Novelli et al. [2], particularly in between the main coastal cities. For example, Camocim (CE), located between São Luís (MA) and Fortaleza (CE), is a peculiar location, with extreme values: the highest values for "Annual mean temperature", "Max temperature of warmest month", "Mean temperature of warmest and coldest quarter", "Mean diurnal range", "Precipitation seasonality", "Potential of Evapotranspiration" and the lowest for "Precipitation of driest quarter" (Table 5). 
Table 5. Comparison of the minimum and maximum values of the environmental variables and their geographical location based on the results of Schaeffer-Novelli et al. [2] and the present study. * The maximum values of SSTMAX are found in four locations: Chaves, near to Bragança (PA) and two others locations in between São Luiz (MA) and Parnaiba (PI).

\begin{tabular}{|c|c|c|c|c|c|c|c|c|c|c|}
\hline \multirow{2}{*}{ Variables } & & \multirow{2}{*}{ Codes } & \multicolumn{2}{|c|}{ This Study } & \multicolumn{2}{|c|}{ S-N et al. (1990) } & \multicolumn{2}{|r|}{ This Study } & \multicolumn{2}{|c|}{ S-N et al. (1990) } \\
\hline & & & Min & Location & Min & Location & Max & Location & Max & Location \\
\hline Annual Mean Temperature & \multirow{12}{*}{ Group 1} & $\mathrm{BIO1}$ & 19.8 & $\begin{array}{l}\text { Florianópolis/Biguaçu, } \\
\text { SC }\end{array}$ & $<20$ & Laguna, SC & 27.9 & Camocim, CE & ca. 26.8 & Recife, PE \\
\hline Isothermality & & $\mathrm{BIO} 3$ & 43 & Laguna, SC & & & 89 & near to Belém, PA & & \\
\hline Temperature Seasonality & & $\mathrm{BIO} 4$ & 306 & near to Belém, PA & & & 3129 & Paranaguá Bay, PR & & \\
\hline Temperature Annual Range & & $\mathrm{BIO} 7$ & 8.5 & Aracajú, SE & $>1$ & Belém, PA & 18.3 & Camboriú, SC & $>8$ & Laguna, SC \\
\hline Mean Temperature of Driest Quarter & & BIO9 & 16.2 & Camboriú, SC & & & 28.2 & Acaraú, CE & & \\
\hline Mean Temperature of Warmest Quarter & & BIO10 & 23.2 & Florianópolis, SC & & & 28.7 & Camocim, CE & & \\
\hline Min Temperature of Coldest Month & & BIO6 & 10.4 & Camboriú, SC & 15.7 & Laguna, SC & 23.2 & Marajó Island, PA & ca. 25.5 & Belém, PA \\
\hline Mean Temperature of Coldest Quarter & & BIO11 & 16.2 & $\begin{array}{l}\text { Camboriú/Biguaçu, } \\
\text { SC }\end{array}$ & & & 27.1 & Camocim, CE & & \\
\hline Min Sea surface temperature & & SSTMIN & 17 & Laguna, SC & & & 30 & Icatu, MA & & \\
\hline Mean Sea surface temperature & & SSTMEAN & 21.50 & Imbituba, SC & & & 31.21 & Bequimão, MA & & \\
\hline Max Sea surface temperature & & SSTMAX & 25 & Imbituba, SC & & & 33 & ${ }^{*}$ Four locations & & \\
\hline Precipitation of Warmest Quarter & & $\mathrm{BIO} 18$ & 7 & Cajueiro da Praia, PI & & & 1029 & Cananéia, SP & & \\
\hline Mean Diurnal Range & \multirow{7}{*}{ Group 2} & $\mathrm{BIO} 2$ & 57 & Aracajú, SE & & & 110 & Camocim, CE & & \\
\hline Mean Temperature of Wettest Quarter & & $\mathrm{BIO} 8$ & 22.5 & Belmonte, BA & & & 27.6 & Areia Branca, RN & & \\
\hline Max Temperature of Warmest Month & & BIO5 & 27.6 & Laguna, SC & & & 35.1 & Camocim, CE & & \\
\hline Precipitation Seasonality & & BIO15 & 9 & Una, BA & & & 118 & Camocim, CE & & \\
\hline Precipitation of Driest Month & & BIO14 & 0 & Macau, RN & & & 143 & Camamu/Maraú, BA & & \\
\hline Precipitation of Driest Quarter & & BIO17 & 1 & Camocim, CE & & & 466 & Camamu/Maraú, BA & & \\
\hline Potential Evapotranspiration & & PET & 1092 & Madre River, SC & ca. 950 & $\begin{array}{l}\text { Florianópolis, } \\
\text { SC }\end{array}$ & 1877 & Camocim, CE & 1600 & $\begin{array}{c}\text { Golfão-Belém, } \\
\text { PA }\end{array}$ \\
\hline Annual Precipitation & \multirow{6}{*}{ Group 3} & BIO12 & 600 & Macau, RN & \multirow[t]{6}{*}{1090} & \multirow[t]{6}{*}{$\begin{array}{l}\text { Rio de } \\
\text { Janeiro, RJ }\end{array}$} & 3791 & Nazaré, AP & 3250 & Maracá, AP \\
\hline Precipitation of Wettest Month & & BIO13 & 114 & Arraial do Cabo, RJ & & & 613 & Algodoal, PA & & \\
\hline Precipitation of Wettest Quarter & & BIO16 & 300 & Arraial do Cabo, RJ & & & 1655 & Nazaré, AP & & \\
\hline Precipitation of Coldest Quarter & & BIO19 & 61 & Areia Branca, RN & & & 1634 & Marajó Island, PA & & \\
\hline Aridity index & & ARIDITY & 0.36 & Macau, RN & & & 2.38 & Nazaré, AP & & \\
\hline Salinity & & SALINITY & 27.96 & $\begin{array}{l}\text { Oiapoque River, } \\
\text { AM }\end{array}$ & & & 37.17 & Belmonte, BA & & \\
\hline
\end{tabular}


For the "Annual mean temperature", Schaeffer-Novelli et al. [2] found almost the same values as we did, however, we found them in different locations. In contrast, the minimum value of the "Min temperature of coldest month" that we found in Brazilian mangroves was $10.4{ }^{\circ} \mathrm{C}$ against $15.7^{\circ} \mathrm{C}$ found by Schaeffer-Novelli et al. [2]. While just considering the southern mangrove limits, the min temperature of the coldest month that we found is $12.5^{\circ} \mathrm{C}$ that differs $3.2^{\circ} \mathrm{C}$ with that of previous works $\left(15.7^{\circ} \mathrm{C}\right)[2,68]$. Soares et al. [68] also found $15.7^{\circ} \mathrm{C}$ as a minimum air temperature in Laguna based on 55 years of monitoring at the Laguna meteorological station, operated by the Centro de Informações de Recursos Ambientais e de hidrometeorologia of Santa Catarina (CIRAM). This difference cautions us not to deliberate about climate change while we still are debating about the actual minimum temperature at the limits. Current research about the species distribution modelling and their extent range usually incorporate the same climate database $[69,70]$ as we did. Also, Quisthoudt et al. [67] working on mangrove limits worldwide found the minimum air temperature of the coldest month for Rhizophora species to be $13.1^{\circ} \mathrm{C}$. However, just for the Brazilian mangroves, we found the minimum temperature of the coldest month at the limits of Rhizophora mangle in Praia do Sonho to be $12.8^{\circ} \mathrm{C}$, and from here towards the north, the temperature decreases to $11.3^{\circ} \mathrm{C}$ in Praia Brava in Itajaí (ca. $110 \mathrm{~km}$ north of Praia do Sonho).

According to Schaeffer-Novelli et al. [2] in between Fortaleza (CE) and Rio de Janeiro the rainfall and the potential of evapotranspiration are similar throughout the year with a seasonal climate. Indeed, taking into account the annual precipitation in the cities of Fortaleza and Rio de Janeiro they are apparently similar around 1315 to $1450 \mathrm{~mm}$, respectively. However, our results contrast their findings and show strong variability within and between these cities (Figure 7). For example, in Ceará the annual precipitation ranges between $937 \mathrm{~mm}$ and $1429 \mathrm{~mm}$, in Rio Grande do Norte between 600 mm and 1624 mm, in Paraíba between 1665 and 2097 mm, in Pernambuco between 1686 and 2098 $\mathrm{mm}$, in Alagoas between 1321 and 1794, and in Sergipe between 1327 and $1673 \mathrm{~mm}$, indicating that the states of Paraíba and Pernambuco on one hand, and the states of Alagoas and Sergipe on the other hand, have a similar range. In Bahia, we found about 41\% intra-state variation for the "Annual precipitation" with a minimum of $990 \mathrm{~mm}$ and a maximum of $2414 \mathrm{~mm}$. Espírito Santo has a low annual precipitation variation between 1003 and $1340 \mathrm{~mm}$, but in Rio de Janeiro we found a huge variation between 870 and $2182 \mathrm{~mm}$. The high annual precipitation variability in Bahia and Rio de Janeiro can be explained by the large coastline and a significant latitudinal variation that provides a wide range of environmental conditions, but also due to the seasonal upwelling events that changes the climate conditions. In Bahia this is evident through the fluctuations of the Annual precipitation and for the precipitation of the driest quarter.

We also found extremely different results for the maximum and minimum values of "Annual precipitation" when compared with the previous study by Schaeffer-Novelli et al. [2]. For instance, we found the record with the minimum "Annual mean precipitation" to be $600 \mathrm{~mm}$ and to originate from Macau, whereas Schaeffer-Novelli et al. [2] found it to be $1090 \mathrm{~mm}$ and to originate from Rio de Janeiro, which is a difference of $490 \mathrm{~mm}$ from two sites $>2000 \mathrm{~km}$ apart. However, Schaeffer-Novelli et al. [2] also found fairly low values in Aracajú (ca. $1150 \mathrm{~mm}$ ) and in Fortaleza (ca. $1200 \mathrm{~mm}$ ) about $650 \mathrm{~km}$ and $260 \mathrm{~km}$ distance from Macau, respectively. Likewise, we found the maximum "Annual precipitation" to be $3791 \mathrm{~mm}$ originating from Nazaré (AM) against $3250 \mathrm{~mm}$ found in Macapá in the same state (Table 5), amounting to a difference of $541 \mathrm{~mm}$. In the mangroves next to Macapá we found values for the annual precipitation in between 3110 and $2710 \mathrm{~mm}$, which are lower than the previous study [2].

\subsection{Mangrove Mappings}

In this study, we found differences between the three most recent global mangrove mapping exercises [7-9] with respect to the southernmost mangrove limits in Brazil. In contrast to Spalding et al. [7], the online datasets for both Spalding et al. [8] and Giri et al. [9] give a seemingly erroneous southernmost limit of mangroves in Brazil that is shown in Guarda do Embaú and next to Imbituba, respectively, instead of Laguna as indicated by Schaeffer-Novelli et al. [2], Spalding et al. [7] and 
Quisthoudt et al. [67]. In Giri et al. [9], the southernmost mangrove is close to Imbituba (SC), about 7 $\mathrm{km}$ from the coast located in the sea, however, we did not localize this mangrove position in any other mapping or reference. In addition, this location seems erroneous because we did not find an island that could make the establishment of mangroves possible. Therefore, we localize a nearest estuary using the high-resolution images on Google Earth in the surroundings of Imbituba (SC), that is, we moved this point from the sea to the nearest estuary.

\subsection{Limitation of This Work}

We analyzed the species assuming a continuous distribution, mainly owing to a lack of a reliable data of the species distribution and the fact that Brazilian mangrove species are usually mapped as though they had a continuous distribution from the northern to the southern limits [8]. However, a study conducted by Menezes et al. [71] in the Amazonia mangroves has shown that R. racemosa and $R$. harrisonii has a disjunct distribution. Wherever available, we used site-specific information (the absence of $R$. mangle in Camboriú), but given that this information is not systematically available for all species, we often focused on the limits of all species, keeping in mind the environmental range that species had to go through to reach their limit in the direction of higher latitudes.

Twilley et al. [72] developed a hierarchical classification system based on several studies related to the species distribution at different scales, and they showed that the main factor for the distribution of species at global scale is temperature. At others scales, the geomorphology types (i.e., Lagoon, Delta, Estuary) and ecological type (i.e., Basin, Fringe, Riverine and Scrub) [73] can also influence the distribution of species. However, considering the entire and latitudinally wide Brazilian mangrove coastline, and despite the species' distribution discontinuity, we were able to characterize mangroves at regional scale based on climate rather than local factors.

This study did not include the "tidal amplitude" as a variable. However, since "tidal amplitudes decrease southward along the Brazilian coast", as reported by Schaeffer-Novelli et al. [2], this variable undoubtedly correlates with other variables that follow a latitudinal gradient, but without any causal or relation whatsoever between these variables. On local scale, tide inundation, frequency and amplitude are important ecohydrological factors determining the mangrove zonation by limiting excessive build-up of salt within soil, controlling propagule dispersion [51], and other factors. However, on regional or global scales the distribution of species is more influenced by climate factors $[72,74]$ than by local factors, such as tide.

The SST used in this study was obtained from global MODIS ocean water temperature surfaces. However, the local water temperature in mangroves will probably be higher than that of MODIS, because the soil absorbs the solar radiation and this process may also increase the local water temperature in contact with the warmer soil. In addition, the turbidity of the shallow coastal waters is known to affect the reflectance of the Sun, which in turn interferes with the radiometric determination of the SST. This local influence is a typical circumstance of Case II waters, that are affected by dissolved organic matter of terrestrial origin, inorganic mineral particles and various suspended sediments, in addition to phytoplankton and their associated debris. Although, in situ measurements are usually taken to calibrate the MODIS data [39], differences between surface data and field data may continue to exist. In any case, for this work on the characterization of mangroves along the Brazilian coastline, there were not enough local (in lagoons, mangrove creeks, etc.) temperature measurements at the scale of our study. In addition, variations may occur inside lagoons (Figure 10). 


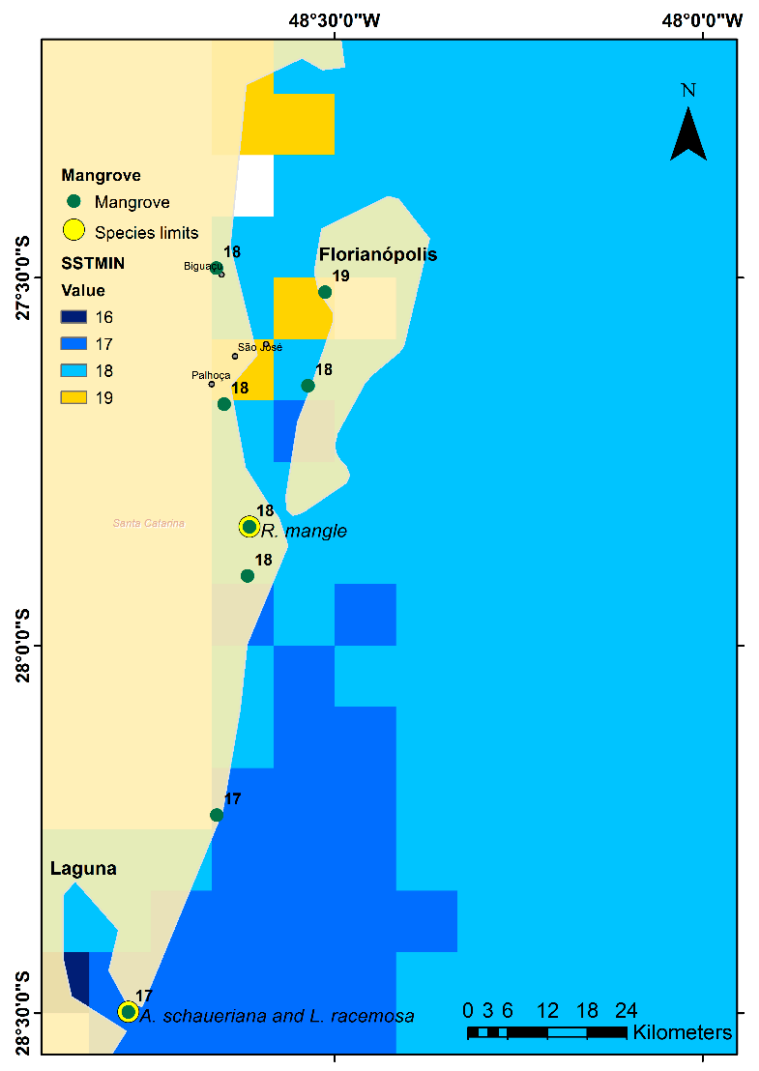

Figure 10. SSTMIN variation at the southernmost limit. Map showing the distribution and variation of SSTMIN at the mangrove limits in the state of Santa Catarina. Note that within Laguna, the SSTMIN variation ranges over $16^{\circ} \mathrm{C}, 17^{\circ} \mathrm{C}$ and $18^{\circ} \mathrm{C}$, averaging to $17^{\circ} \mathrm{C} \pm 1{ }^{\circ} \mathrm{C}$. The yellow circle corresponds to the southernmost mangrove limits in Brazil.

The same global versus local discussion can be valid for the air temperature stemming from the WorldClim database. WorldClim is a historical meteorological database with data from several stations worldwide that were interpolated using latitude, longitude and altitude as independent variables, creating what is called a climate surface. These climate surfaces allow us to estimate the climate in areas where there is a lack of climate data. For this reason, the proposed method enabled us to measure and cover climate gaps existing in previous studies [2,74].

The atmospheric climate variables are reliably observed by a limited number of meteorological stations [75], and according to Hijmans et al. [4] the geographic distribution of the stations is clearly not random and there are few stations in areas with low population density, such as in the Amazon. Possibly, a denser network of weather stations, more effectively covering the Brazilian coast would lead to finer results. The Worldclim database, however, already has a 400 times higher spatial resolution than previously available surfaces with more weather stations and more accurate global elevation data [4].

The ocean surface salinity was used in this research to understand the regional variation of salinity along the Brazilian coast, as ocean currents and the physicochemical properties of the water are of direct importance for the nautohydrochorous propagules [76]. The low ocean salinity found in the north of Brazil is probably due to the high precipitation and the huge freshwater discharge in the Atlantic Ocean from large rivers, such as the Amazon. The highest value of salinity from our database did not exceed 37 PSU, but local values of salinity have a strong variation on short distances and are known to have a high impact on mangrove ecosystems: depending on the topographical elevation and the season, the salinity in Bragança, for instance can range from 10 to 90 PSU [77]. Even in the north 
of Brazil where a high annual precipitation occurs, a prominent dry season, hypersaline conditions and rarely inundated areas can be found, resulting in monospecific dwarf mangrove forests [77-79]. In addition, higher values of salinity have been reported from other sites in the world [80-82]. For this reason, the salinity ocean surface used in this research did not bring enough relevant information to understand the species distribution.

\section{Conclusions}

The objectives of this study were achieved for the Brazilian mangroves. First, our study provides significant improvement to update the information regarding to climate using recent databases overcoming data gaps in previous studies $[2,68]$. These improvements have led us to the identification and location of extreme maximum and minimum values that differ from previous studies for certain variables. Second, relevant climate variables were exposed according to their spatial dependence, and three groups of variables were divided using the SOM-PCA geovisualization tools, which forms a new approach for mangrove studies. Third, this study could provide a better understanding of the fundamental niche for mangrove plant species giving insights about their distribution related to bioclimate factors.

In this sense, according to our findings the R. racemosa and $R$. harrisonii seem limited by extremely low precipitation during the dry season, i.e., the high precipitation component planes coincide with the northeastern limits of the two species of Rhizophora. Because there is hardly any latitudinal variation in the coastline with suitable temperatures beyond their limits, temperature is not the main factor for these two species. In this sense, like others authors [51-53], we also conclude that when precipitation is the main limiting factor for a certain species' distribution, the declining of richness does not necessary follow a latitudinal gradient.

However, species that are more likely to be limited by temperature gradually follow the latitudinal gradient, which is the case for A. germinans, C. erectus, $R$. mangle, A. schaueriana and L. racemosa. In addition, we highlight the importance of the upwelling conditions that might be a barrier for $A$. germinans and C. erectus, but further investigation should be done in this respect.

However, our data indicate that the lowest min air temperatures of the coldest month are located at the mesoregion of Vale do Itajaí and not in the southernmost limit of mangroves, as we expected. Nevertheless, the SSTMIN follow gradually the latitudinal variation with the lowest values in the southernmost limit. For this reason, we believe that it is instead the minimum sea surface temperature that has a major influence on mangrove species distribution, rather than any other air temperature or mean or max sea surface temperature. Dana [83] made an observation on marine animals very close to what we found: "The cause which limits the distribution of species northward or southwards from the equator is the cold of winter rather than the heat of summer or even the mean temperature of the year".

This study also provides new information about the Brazilian mangroves characterizing it mostly in humid areas, with few exceptions in dry sub-humid and semi-arid areas in restricted regions in the northeastern states. The spatial localization of these sub-humid and semi-arid areas have never been identified by previous studies $c f$. [2,69]. In addition, we provide a pre-selection criterion for the bioclimatic variables that have been largely used as input data for species distribution modeling and/or environmental mapping. The pre-selection of the three groups of variables reduces the dimensionality of the data and it facilitates the analysis of modeling activities.

The reduction of dimensionality as the main characteristic of SOM methods did not give us detailed information of variables versus species limits. Therefore, descriptive statistical analyses, such as scatterplots and spatialization of the variables, are highly recommended to complement the SOM methods, and provide the extra detail needed to understand the possible influence of the variables on the species limits.

In this study, we also found some contradictions between the most recent mappings of mangroves that are important to emphasize. The most visible differences are based on the fact that the two most 
recent mappings [8,9] have ignored the southernmost limits of mangroves and only the old version of the World Mangrove Atlas [7] has properly mapped it. This gap could be explained by the fact that at their limits mangroves are scarce, so maybe they did not reach the minimum size area to be mapped by these new methods of classification. The mangrove limits at higher latitudes have important ecological aspects to be studied and they should not be ignored in global mappings. However, we also recognize the excellent effort of these two most recent worldwide mappings [8,9], because they continue to provide useful higher resolution global mappings for conservation projects and scientific studies.

The study of Schaeffer-Novelli et al. [2] was a very important review of the environmental and physiographic characterization of the Brazilian mangroves. In the 1990s, this work gave us an important overview the Brazilian mangroves and their relation to climate. However, nowadays a huge amount of information is available from satellite images and interpolated climate surfaces, providing new input data for such an analysis. For this reason, policy makers and other stakeholders may find the method proposed here useful for designing conservation strategies since it offers a more correct, complete and updated analysis of environmental factors driving mangrove tree distribution, or driving the distribution of any other coastal system (e.g., seagrass beds and coral reefs). If the design of policy, governance and management rules were to divide the Brazilian coast into sections, such as in Schaeffer-Novelli et al. [2], reliable data are paramount. For future research, we expect to expand this climate framework on a global scale.

Acknowledgments: The first author is grateful to the financial and administrative authorities at the Brazilian scholarship Ciências sem Fronteiras (Science without Borders) CNPq (201782/2014-6) and to the Belgian National Science Foundation FNRS ('Mandat d'Impulsion Scientifique' MIS ID 1765914) for the PhD scholarship (2011-2014). The publication was made possible with financial support of the University Foundation of Belgium (Universitaire Stichting van België/Fondation Universitaire de la Belgique US-FU). The authors also wishes to thank ESRI for supporting this conservation project with the license of the ArcGIS 10. We are also grateful to the internship students from the program of Science without Borders: Maria Flavia Barbosa Xavier and Gabriel Matos that helped the cleaning the raw data at the beginning of this research. Eduardo Maeda is funded by the Academy of Finland.

Author Contributions: This research is part of the PhD thesis of Arimatéa C. Ximenes who led the research and conceptual design, data processing, GIS, statistical analysis and wrote the article. Farid Dahdouh-Guebas supervised the research and provided substantial contribution in writing and revising the manuscript. Eduardo E. Maeda helped in revising the manuscript and gave insights for the figures and graphs. Gustavo F.B. Arcoverde contributed in revisions and comments, mainly in his specialty of SOM methods. All authors have read and approved the final version of this manuscript.

Conflicts of Interest: The authors declare no conflict of interest.

\section{References}

1. Pugnaire, F.I.; Valladares, F. Functional Plant Ecology; CRC Press/Taylor \& Francis Group: Boca Raton, FL, USA, 2007.

2. Schaeffer-Novelli, Y.; Cintrón-Molero, G.; Adaime, R.R.; Camargo, T.M. Variability of mangrove ecosystems along the Brazilian coast. Estuaries 1990, 13, 204-218. [CrossRef]

3. de Larcila, L.N.; Morellato, L.P.C.; Machado, I.C. Reproductive phenology of a northeast Brazilian mangrove community: Environmental and biotic constraints. Flora Morphol. Distrib. Funct. Ecol. Plants 2012, 207, 682-692.

4. Hijmans, R.J.; Cameron, S.E.; Parra, J.L.; Jones, P.G.; Jarvis, A.J. Very high resolution interpolated climate surfaces for global land areas. Int. J. Climatol. 2005, 25, 1965-1978. [CrossRef]

5. Boyer, T.P.; Antonov, J.I.; Baranova, O.K.; Garcia, H.E.; Johnson, D.R.; Locarnini, R.A.; Mishonov, A.V.; O’Brien, T.D.; Seidov, D.; Smolyar, I.V; et al. World Ocean Database 2009; Levitus, S., Ed.; NOAA Atlas. U.S. Gov. Printing Office: Washington, DC, USA, 2009.

6. Feldman, G.C.; McClain, C.R. Ocean Color Web. Available online: http://oceancolor.gsfc.nasa.gov/ (accessed on 12 Februray 2015).

7. Spalding, M.; Blasco, F.; Field, C. World Mangrove Atlas; International Society for Mangrove Ecosystems: Okinawa, Japan, 1997. 
8. Spalding, M.; Kainuma, M.; Collins, L. World Atlas of Mangroves; Earthscan: London, UK, 2010.

9. Giri, C.; Ochieng, E.; Tieszen, L.L.; Zhu, Z.; Singh, A.; Loveland, T.; Masek, J.; Duke, N. Status and distribution of mangrove forests of the world using earth observation satellite data. Glob. Ecol. Biogeogr. 2011, 20, 154-159. [CrossRef]

10. Newman, H.B.; Ellisman, M.H.; Orcutt, J.A. Data-intensive e-science frontier research. Commun. ACM 2003, 46, 68-77. [CrossRef]

11. Kelling, S.; Hochachka, W.M.; Fink, D.; Riedewald, M.; Caruana, R.; Ballard, G.; Hooker, G. Data-intensive science: A new paradigm for biodiversity studies. Bioscience 2009, 59, 613-620. [CrossRef]

12. Kumpumäki, T.; Ruusuvuori, P.; Kangasniemi, V.; Lipping, T. Data-driven approach to benthic Cover type classification using bathymetric LiDAR waveform analysis. Remote Sens. 2015, 7, 13390-13409. [CrossRef]

13. Kohonen, T. Self-organized formation of topologically correct feature maps. Biol. Cybern. 1982, 43, 59-69. [CrossRef]

14. Kohonen, T. Self-Organizing Maps, 3rd ed.; Springer-Verlag Berlin Heidelberg: Berlin/Heidelberg, Germany, 2001.

15. Koua, E.L.; Maceachren, A.; Kraak, M.-J. Evaluating the usability of visualization methods in an exploratory geovisualization environment. Int. J. Geogr. Inf. Sci. 2006, 20, 425-448. [CrossRef]

16. Ximenes, A.C. Mapas Auto-Organizáveis para a Identificação de Ecorregiões no Interflúvio Madeira-Purus: Uma Abordagem da Biogeografia Ecológica; Instituto Nacional de Pesquisas Espaciais: São José dos Campos, Brazil, 2008.

17. Ximenes, A.C.; Amaral, S.; Monteiro, A.M.V.; Valeriano, D.M. A Self-organized map neural network approach for ecoregions mapping at Brazilian Amazon Forest. In First Latin American Landscape Ecology Conference; International Association for Landscape Ecology (IALE): Campos do Jordão, Brazil, 2009.

18. Ximenes, A.C.; Amaral, S.; Valeriano, D.M. Os impactos dos cenários gerais de mudanças climáticas sobre as ecorregiões da Amazônia Legal; INPE: São José dos Campos, Brazil, 2012.

19. Fendereski, F.; Vogt, M.; Payne, M.R.; Lachkar, Z.; Gruber, N.; Salmanmahiny, A.; Hosseini, S.A. Biogeographic classification of the Caspian Sea. Biogeosciences 2014, 11, 6451-6470. [CrossRef]

20. Pérez-Hoyos, A.; Martínez, B.; García-Haro, F.; Moreno, Á.; Gilabert, M. Identification of ecosystem functional types from coarse resolution imagery using a self-organizing map approach: A case study for Spain. Remote Sens. 2014, 6, 11391-11419. [CrossRef]

21. Arcoverde, G.F.B.; Almeida, C.M.; Ximenes, A.C.; Maeda, E.E.; Araújo, L.S. de Identificação de áreas prioritárias para recuperação florestal com o uso de rede neural de mapas auto-organizáveis. Bol. Ciências Geodésicas 2011, 17, 379-400. [CrossRef]

22. Ximenes, A.C.; Amaral, S.; Arcoverde, G.F.B.; Monteiro, A.M.V. Redes neurais para a seleção de variáveis ambientais no processo de modelagem de distribuição de espécies na região Norte do Brasil. In XIV Simpósio Brasileiro de Sensoriamento Remoto; INPE: Natal, Brazil, 2009; pp. 5531-5538.

23. Vesanto, J.; Himberg, J.; Alhoniemi, E.; Parhankangas, J. SOM Toolbox for Matlab. Available online: http:/ / www.cis.hut.fi/somtoolbox/ (accessed on 26 May 2016).

24. Giraudel, J.L.; Lek, S. A comparison of self-organizing map algorithm and some conventional statistical methods for ecological community ordination. Ecol. Modell. 2001, 146, 329-339. [CrossRef]

25. Crisci, J.V.; Sala, O.E.; Katinas, L.; Posadas, P. Bridging historical and ecological approaches in biogeography. Aust. Syst. Bot. 2006, 19, 1-10. [CrossRef]

26. Hutchinson, G.E. Concluding Remarks. Cold Spring Harb. Symp. Quant. Biol. 1957, 22, 415-427. [CrossRef]

27. FAO. The World's Mangroves 1980-2005; FAO Forest.; Food and Agricultural Organization: Rome, Italy, 2007.

28. Saenger, P.; Hegerl, E.J.J.; Davie, J.D.S. Global status of mangrove ecosystems. Environmentalist 1983, 3, 80-88.

29. Lacerda, L.; Conde, J.E.; Alarcon, C.; Alvarez-León, R.; Bacon, P.; D’Croz, L.; Kjerfve, B.; Polanía, J.; Vannucci, M. Mangrove Ecosystems of Latin America and the Caribbean: A Summary; Lacerda, L.D., Ed.; Mangrove Ecosystems Technical Reports; International Society for Mangrove Ecosystems: Okinawa, Japan, 1993.

30. Kuenzer, C.; Bluemel, A.; Gebhardt, S.; Quoc, T.V.; Dech, S. Remote sensing of mangrove ecosystems: A review. Remote Sens. 2011, 3, 878-928. [CrossRef]

31. Heumann, B.W. Satellite remote sensing of mangrove forests: Recent advances and future opportunities. Prog. Phys. Geogr. 2011, 35, 87-108. [CrossRef] 
32. Kovacs, J.M.; King, J.M.L.; Flores de Santiago, F.; Flores-Verdugo, F. Evaluating the condition of a mangrove forest of the Mexican Pacific based on an estimated leaf area index mapping approach. Environ. Monit. Assess. 2009, 157, 137-149. [CrossRef] [PubMed]

33. McCarthy, M.J.; Merton, E.J.; Muller-Karger, F.E. Improved coastal wetland mapping using very-high 2-meter spatial resolution imagery. Int. J. Appl. Earth Obs. Geoinf. 2015, 40, 11-18. [CrossRef]

34. Ximenes, A.C. Global mangrove mapping: A critical tool for conservation. GLP News 2015, 12, 65-69.

35. Zomer, R.J.; Trabucco, A.; Van Straaten, O.; Bossio, D.A. Carbon, Land and Water: A Global Analysis of the Hydrologic Dimensions of Climate Change Mitigation through Afforestation/Reforestation; IWMI Resea; International Water Management Institute: Colombo, Sri Lanka, 2006; Volume 101.

36. Zomer, R.J.; Trabucco, A.; Bossio, D.A.; van Straaten, O.; Verchot, L.V. Climate change mitigation: A spatial analysis of global land suitability for clean development mechanism afforestation and reforestation. Agric. Ecosyst. Environ. 2008, 126, 67-80. [CrossRef]

37. United Nations Environment Programme (UNEP). World Atlas of Desertification, 2nd ed.; UNEP: London, UK, 1997.

38. Tyberghein, L.; Verbruggen, H.; Pauly, K.; Troupin, C.; Mineur, F.; De Clerck, O. Bio-ORACLE: A global environmental dataset for marine species distribution modelling. Glob. Ecol. Biogeogr. 2012, 21, 272-281. [CrossRef]

39. Brown, O.B.; Minnett, P.J. MODIS Infrared Sea Surface Temperature Algorithm (ATBD 25, v2); University of Miami: Miami, FL, USA, 1999.

40. Vesanto, J. Data Exploration Process Based on the Self-Organizing Map; Helsinki University of Technology: Tieteiden, (Helsinki) Teknillisten, 2002.

41. Astel, A.; Tsakovski, S.; Barbieri, P.; Simeonov, V. Comparison of self-organizing maps classification approach with cluster and principal components analysis for large environmental data sets. Water Res. 2007, 41, 4566-4578. [CrossRef] [PubMed]

42. Ultsch, A. Knowledge extraction from self-organizing neural networks. In Information and Classification; Opitz, O., Lausen, B., Klar, R., Eds.; Springer: Berlin/Heidelberg, Germany, 1993; pp. 301-306.

43. Poncelet, P.; Masseglia, F.; Teisseire, M. Successes and New Directions in Data Mining; Information Science Reference-Imprint of IGI Publishing: Hershey, PA, USA, 2007.

44. Brereton, R.G. Self organising maps for visualising and modelling. Chem. Cent. J. 2012, 6, S1. [CrossRef] [PubMed]

45. MATLAB Matlab Version 7.10.0 (R2010a) Natick, Massachusetts; The MathWorks Inc.: Natick, MA, USA, 2010.

46. Ellison, A.M. Macroecology of mangroves: Large-scale patterns and processes in tropical coastal forests. Trees 2002, 16, 181-194. [CrossRef]

47. Ricklefs, R.E.; Latham, R.E.; Ricklefs, R.E.; Latham, R.E. Global patterns of diversity in mangrove floras. In Species Diversity in Ecological Communities: Historical and Geographical Perspectives; Ricklefs, R.E., Schluter, D., Eds.; University of Chicago Press: Chicago, IL, USA, 1993; pp. 215-229.

48. Wade, T.; Sommer, S. A to Z GIS: An Illustrated Dictionary of Geographic Information Systems, 2nd ed.; Esri Press: Redlands, CA, USA, 2006.

49. Anselin, L.; Syabri, I.; Kho, Y. GeoDa: An introduction to spatial data analysis. Geogr. Anal. 2006, 38, 5-22. [CrossRef]

50. Environmental Systems Research Institute. ESRI ArcGIS Desktop Release 10; Environmental Systems Research Institute: Redlands, CA, USA, 2011.

51. Saenger, P. Mangrove Ecology, Silviculture and Conservation; Springer: Dordrecht, The Netherlands, 2002.

52. Saenger, P.; Moverley, J. Vegetative phenology of mangroves along the Queensland coastline. Proc. Ecol. Soc. Aust. 1985, 13, 257-265.

53. Smith, T.J.; Duke, N.C. Physical determinants of inter-estuary variation in mangrove species richness around the tropical coastline of Australia. J. Biogeogr. 1987, 14, 9-19. [CrossRef]

54. Jiménez, J.A.; Sauter, K. Structure and dynamics of mangrove forests along a flooding gradient. Estuaries 1991, 14, 49-56. [CrossRef]

55. Kottek, M.; Grieser, J.; Beck, C.; Rudolf, B.; Rubel, F.; Centre, P.C.; Wetterdienst, D. World map of the Köppen-Geiger climate classification updated. Meteorol. Z. 2006, 15, 259-263. [CrossRef] 
56. Kampel, M.; Lorenzetti, J.A.; Silva, C.L., Jr. Observação por satélite de ressurgências na costa S-SE brasileira. In Congresso Latino-AMERICANO sobre Ciências do Mar (Colacmar); Colacmar: Santos-SP, Brazil, 1997; pp. 38-40.

57. Oliveira Filho, E.C. Algas Marinhas Bentônicas do Brasil; Universidade de São Paulo: São Paulo, Brazil, 1977.

58. Yoneshigue, Y. Taxonomie et ecologie des algues marines dans la région de Cabo Frio (Rio de Janeiro, Brésil); Université d'Aix Marseille: Marseille, France, 1985.

59. Guimaraens, M.A.; Coutinho, R. Spatial and temporal variation of benthic marine algae at the Cabo Frio upwelling region, Rio de Janeiro, Brazil. Aquat. Bot. 1996, 52, 283-299. [CrossRef]

60. Martin, L.; Flexor, J.M.; Valentin, J.L. The influence of the "El Niño" phenomenon on the enhancement or annihilation of Cabo Frio upwelling on the Brazilian coast of the State of Rio de Janeiro. In International Symposium on Global Changes in South America during the Quaternary. Special Publ. No. 1.; Associação Brasileira de Estudos do Quaternário: São Paulo, Brésil, 1989; pp. 225-227.

61. Valentin, J. Analyses des paramètres hidrobiologiques darts la remontée de Cabo Frio (Brésil). Mar. Biol. 1984, 82, 259-276. [CrossRef]

62. Calado, L.; da Silveira, I.C. A.; Gangopadhyay, A.; de Castro, B.M. Eddy-induced upwelling off Cape São Tomé (22ㅇ, Brazil). Cont. Shelf Res. 2010, 30, 1181-1188. [CrossRef]

63. McMillan, C. Environmental factors affecting seedling establishment of the black mangrove-D on the central Texas coast. Ecology 1971, 52, 927-930. [CrossRef]

64. Tognella, M.M.P.; Oliveira, R.G. Manguezal do Rio Camboriú: Dados preliminares. Enciclopédia Biosf. 2012, 8, 1828-1844.

65. Massó i Alemán, S.; Bourgeois, C.; Appeltans, W.; Vanhoorne, B.; De Hauwere, N.; Stoffelen, P.; Heughebaert, A.; Dahdouh-Guebas, F. The “Mangrove Reference Database and Herbarium”. Plant Ecol. Evol. 2010, 143, 225-232. [CrossRef]

66. Stuart, S.A.; Choat, B.; Martin, K.C.; Holbrook, N.M.; Ball, M.C. The role of freezing in setting the latitudinal limits of mangrove forests. New Phytol. 2007, 173, 576-583. [CrossRef] [PubMed]

67. Quisthoudt, K.; Schmitz, N.; Randin, C.F.; Dahdouh-Guebas, F.; Robert, E.M.R.; Koedam, N. Temperature variation among mangrove latitudinal range limits worldwide. Trees 2012, 26, 1919-1931. [CrossRef]

68. Soares, M.L.G.; Estrada, G.C.D.; Fernandez, V.; Tognella, M.M.P. Southern limit of the Western South Atlantic mangroves: Assessment of the potential effects of global warming from a biogeographical perspective. Estuar. Coast. Shelf Sci. 2012, 101, 44-53. [CrossRef]

69. Quisthoudt, K.; Adams, J.; Rajkaran, A.; Dahdouh-Guebas, F.; Koedam, N.; Randin, C. Disentangling the effects of global climate and regional land-use change on the current and future distribution of mangroves in South Africa. Biodivers. Conserv. 2013, 22, 1369-1390. [CrossRef]

70. Record, S.; Charney, N.D.; Zakaria, R.M.; Ellison, A.M. Projecting global mangrove species and community distributions under climate change. Ecosphere 2013, 4. art34. [CrossRef]

71. Menezes, M.P.M.; Berger, U.; Mehlig, U. Mangrove vegetation in Amazonia: A review of studies from the coast of Pará and Maranhão States, North Brazil. Acta Amaz. 2008, 38, 403-420. [CrossRef]

72. Twilley, R.R.; Rivera-Monroy, V.H.; Chen, R.; Botero, L. Adapting an ecological mangrove Model to simulate trajectories in restoration ecology. Mar. Pollut. Bull. 1998, 37, 404-419. [CrossRef]

73. Lugo, A.E.; Snedaker, S.C. The ecology of mangroves. Annu. Rev. Ecol. Syst. 1974, 5, 39-64. [CrossRef]

74. Blasco, F. Climatic factors and the biology of mangrove plants. In The Mangrove Ecosystem: Research Methods; Snedaker, S.C., Snedaker, J.G., Eds.; UNESCO: Bungay, UK, 1983; pp. 18-35.

75. Droogers, P.; Allen, R.G. Estimating reference evapotranspiration under inaccurate data conditions. Irrig. Drain. Syst. 2002, 16, 33-45. [CrossRef]

76. Higazi, L. Dispersion and Establishment of Mangrove Propagules in the Micro-Tidal Area of Pambala-Chilaw Lagoon (Sri Lanka): An Experimental Approach; Vrije Universiteit Brussel: Ixelles, Belgium, 2008.

77. Lara, R.J.; Cohen, M.C.L. Sediment porewater salinity, inundation frequency and mangrove vegetation height in Bragança, North Brazil: An ecohydrology-based empirical model. Wetl. Ecol. Manag. 2006, 14, 349-358. [CrossRef]

78. Santos, M.V.; Zieman, J.C.; Cohen, R.H. Interpreting the upper mid-littoral zonation patterns of mangroves in Maranhão (Brazil) in response to microtopography and hydrology. In Mangrove Ecosystem Studies in Latin America and Africa; Kjerfve, B., Lacerda, L.D., Diop, E.H., Eds.; UNESCO: Paris, France, 1997; p. 149. 
79. Reiser, A. Estimates of Biomass and Productivity in Fringe Mangroves of North-Brazil; University of Bremen: Bremen, Germany, 2003.

80. Matthijs, S.; Tack, J.; van Speybroeck, D.; Koedam, N. Mangrove species zonation and soil redox state, sulphide concentration and salinity in Gazi Bay (Kenya), a preliminary study. Mangroves Salt Marshes 1999, 3, 243-249. [CrossRef]

81. Dahdouh-Guebas, F.; Koedam, N. Are the northernmost mangroves of West Africa viable?-A case study in Banc d'Arguin National Park, Mauritania. Hydrobiologia 2001, 458, 241-253. [CrossRef]

82. Dahdouh-Guebas, F.; De Bondt, R.; Abeysinghe, P.D.; Kairo, J.G.; Cannicci, S.; Triest, L.; Koedam, N. Comparative study of the disjunct zonation pattern of the grey mangrove Avicennia marina (Forsk.) Vierh. in Gazi Bay (Kenya). Bull. Mar. Sci. 2004, 74, 237-252.

83. Dana, J.D. On an isothermal oceanic chart, illustrating the geographical distribution of marine animals. Am. J. Sci. 1853, 16, 314-327.

(C) 2016 by the authors; licensee MDPI, Basel, Switzerland. This article is an open access article distributed under the terms and conditions of the Creative Commons Attribution (CC-BY) license (http://creativecommons.org/licenses/by/4.0/). 